\title{
Variscan granitoids related to shear zones and faults: examples from the Central Sudetes (Bohemian Massif) and the Middle Odra Fault Zone
}

\author{
T. Oberc-Dziedzic $\cdot$ R. Kryza $\cdot$ C. Pin
}

Received: 11 July 2014 / Accepted: 28 January 2015 / Published online: 8 March 2015

(c) The Author(s) 2015. This article is published with open access at Springerlink.com

\begin{abstract}
The granitoid intrusions of the Central Sudetes (CS) and of the Middle Odra Fault Zone (MOFZ), NE part of the Bohemian Massif, are both spatially and temporally related to large-scale shear zones and faults (including possible terrane boundaries) that provided effective channels for melt migration. Summarizing common features of the CS and MOFZ granitoids, we have delineated a set of characteristics of the fault-related and shear zone-related granitoids: (1) they are mainly generated by partial melting of crustal sources, with variable contribution (or no contribution) of mantle materials; (2) the sheet-like, steeply inclined, narrow and rather small granitoid intrusions are emplaced within shear zones at mid-crustal level (c. $20 \mathrm{~km}$ depth), whereas the larger, flat-lying plutons intrude into the upper crust, outside or above these shear zones; (3) the magmatic foliation and lineation in granitoids of the deeper, sheet-like intrusions are concordant with those in the surrounding metamorphic rocks, suggesting that the solidification of granitoids was coeval with the deformation in the shear zones; instead, the magmatic foliation in the shallower and larger dome-like plutons reflects magma flow; (4) ductile, transcurrent movements along the shear zones postdate medium-pressure regional metamorphism
\end{abstract}

Electronic supplementary material The online version of this article (doi:10.1007/s00531-015-1153-7) contains supplementary material, which is available to authorized users.

T. Oberc-Dziedzic $\cdot$ R. Kryza $(\varangle)$

Institute of Geological Sciences, University of Wrocław,

Plac M. Borna 9, 50-204 Wrocław, Poland

e-mail: ryszard.kryza@ing.uni.wroc.pl

C. Pin

Département de Géologie, UMR 6524 CNRS, Université Blaise

Pascal, 5 rue Kessler, 63038 Clermont-Ferrand, France and are accompanied by an increase in the local thermal gradient, as documented by the crystallization of cordierite, andalusite and sillimanite; (5) the increase in the thermal gradient precedes the emplacement of granitoids and their concomitant thermal influence on the country rocks. The granitoids related to the final stages of tectonothermal activity of the shear zones are good-time markers of their evolutionary path.

Keywords Granitoid intrusions $\cdot$ Shear zones $\cdot$ Variscan magmatism · The Sudetes

\section{Introduction}

Magma emplacement along faults and shear zones, and spatial relationships between these structures and granite plutons have been widely discussed (e.g. Paterson and Schmidt 1999; Schmidt and Paterson 2000; Richards 2001; Weinberg et al. 2004, 2006; Paterson 2006; Archanjo et al. 2008). The discussion has focused on the question whether, and to what extent, magma migration is controlled by faults and shear zones, and on the problem of statistical evaluations of spatial and geometric relationships between populations of igneous bodies and structures in various crustal settings (Paterson and Schmidt 1999). Relatively less attention has been paid to the petrology and internal structural features of the fault-related and shear zone-related granitoids. These problems have recently been investigated in the Central Sudetes (CS) granitoid intrusions (NE part of the Bohemian Massif) and in the Middle Odra Fault Zone (MOFZ; the Wrocław granitoids), which are both spatially and temporally related to large-scale faults and shear zones (including postulated terrane boundaries; Fig. 1). 
This study provides a synthesis of the published data on the petrology, geochemistry and age of the Central Sudetes and Wrocław (MOFZ) granitoids, supplemented by new geochemical, $\mathrm{Sr}-\mathrm{Nd}$ radiogenic isotope tracer and geochronological U-Pb zircon (SHRIMP) age results. Based on earlier data and our own observations, we characterize structural patterns, along with spatial and temporal relationships between the granitoids and shear zones. Summarizing common features of the CS granitoids, we delineate a set of characteristics of the fault-related and shear zone-related granitoids.

\section{Geological setting}

The Variscan Belt of Europe, as defined by Suess (1888), extends from Portugal and Spain, through France, Germany and the Czech Republic, to Poland (Fig. 1a). Outside the Alpine realm, the crystalline basement units of the belt crop out in isolated massifs from the Iberian Meseta in Portugal and Spain, through the Armorican Massif and Massif Central in France, the Vosges and Black Forest, to the Bohemian Massif in the east.

The Bohemian Massif, where the study area is located, adjoins Brunovistulicum (Dudek 1980) to the east. The north-easternmost part of the Bohemian Massif and the western part of Brunovistulicum (Fig. 1b) form the Sudetes area, between the WNW-ESE trending Upper Elbe Fault Zone on the SW and the Middle Odra Fault Zone in the NE. The Sudetes (Fig. 1c) is subdivided into the Sudetic Block and the Fore-Sudetic Block, separated by the NWSE trending Sudetic Marginal Fault. To the NE, the ForeSudetic Block adjoins the Middle Odra Fault Zone.

The Sudetes can further be subdivided into the West and Central Sudetes, which both are part of the Bohemian Massif, and the East Sudetes that belong to Brunovistulicum (Dudek 1980; Oberc-Dziedzic et al. 2013; Schulmann and Gayer 2000; Żelaźniewicz 2005; Żelaźniewicz et al. 2009a). The West Sudetes have been interpreted as part of the Saxothuringian Zone, whereas the Central Sudetes straddles the Teplá-Barrandian and Moldanubian zones (Fig. 1a, b; Mazur et al. 2006; Franke 2012). All these zones are considered by some authors as terranes (Matte et al. 1990) of the Armorican Terrane Assemblage (Franke 2000), whereas Brunovistulicum is interpreted as an individual microcontinent (Pharaoh 1999; Schulmann and Gayer 2000) of Avalonian affinity (Finger et al. 2000; Friedl et al. 2000).

The composite Teplá-Barrandian Terrane, in the Central Sudetes section, comprises the basement underlying the SE part of the Intra-Sudetic Basin, the Góry Sowie Massif, together with the surrounding bodies of the Central Sudetic Ophiolite (Figs. 1c, 2), the Kłodzko Metamorphic Unit (Fig. 3), the Nové Město Belt (Fig. 4) and the Zábřeh Unit (Mazur et al. 2006; Franke 2012; Cymerman et al. 1997). The Moldanubian
Fig. 1 (a) Location of the Sudetes (black dot) in the European Variscides; $(b)$ sketch map of the Bohemian Massif (ST-Saxothuringian, TB-Teplá-Barrandian, MO-Moldanubian zones, after Franke 2012) and Brunovistulicum (BV); quadrangle shows the location of the Sudetes; $(c)$ sketch map of the Sudetes; FSB-Fore-Sudetic Block, S-Sudetes, B-Bardo Structural Unit, NM-Niedźwiedź Massif; granitoids of the Odra Fault Zone: GG-Gubin, SrG-Środa Ślaska, SzG-Szprotawa, WrG-Wrocław; granitoids of the ForeSudetic Block: NG-Niemcza, SSG-Strzegom-Sobótka, StGStrzelin, ZG-Žulova; granitoids of the Sudetes: KdG-KudowaOlešnice, KG-Karkonosze, KZG-Kłodzko-Złoty Stok; faults: UEFZ_-Upper Elbe Fault Zone, MIF-Main Intra-Sudetic Fault, SMF-Sudetic Marginal Fault, SOF-Southern Odra Fault, NOFNorthern Odra Fault; thrusts: NT-Nyznerov Thrust, ST-Strzelin Thrust; quadrangles show position of Figs. 2, 3 and 4

Terrane in this area is composed of the Orlica-Śnieżnik Dome, the Staré Město and Kamieniec Zạbkowicki metamorphic belts, the Niedźwiedź Amphibolite Massif, and the Skrzynka Shear Zone (Figs. 2, 3). In the Fore-Sudetic Block, the boundary between the two terranes is drawn along the Niemcza Shear Zone (Fig. 2), i.e. between the Góry Sowie Massif and the Kamieniec Metamorphic Belt. To the south, in the Sudetic Block, this boundary separates the Orlica-Śnieżnik Dome to the east from the Nové Město Belt to the west (Fig. 4).

According to the earlier tectonic concepts (e.g. Franke and Żelaźniewicz 2000), the Orlica-Śnieżnik Dome, Kamieniec Ząbkowicki and Staré Město belts represent an easterly continuation of the Saxothuringian Terrane. In a more recent interpretation by Chopin et al. (2012), this part of the Moldanubian Zone would be merely defined as a recycled passive margin of the Saxothuringian Zone. In this concept, the Orlica-Śnieżnik Dome represents a large gneiss dome created by the expulsion of the previously subducted Saxothuringian crust.

The main deformation in the Teplá-Barrandian Terrane occurred at the turn of the Middle to Late Devonian (see references cited by Dörr and Zulauf 2010; Mazur et al. 2006). During the Late Devonian and Early Carboniferous, the metamorphosed and deformed rocks of that terrane were partly covered by the sediments of the Bardo and Świebodzice basins (Fig. 1c) and, subsequently, starting from the mid-Viséan, by the infill of the Intra-Sudetic Basin (Turnau et al. 2002; Mazur et al. 2006). The main deformation on the Moldanubian Terrane side took place during early Carboniferous times (Chopin et al. 2012; Żelaźniewicz et al. 2014, and references in both). The boundary between the Teplá-Barrandian and Moldanubian terranes was formed at that time, i.e. about $340 \mathrm{Ma}$.

\section{Regional-scale shear zones in the Central Sudetes and the Middle Odra faults}

During the collision of the Central Sudetes with Brunovistulicum in the Early to Late Carboniferous (Matte et al. 1990; 


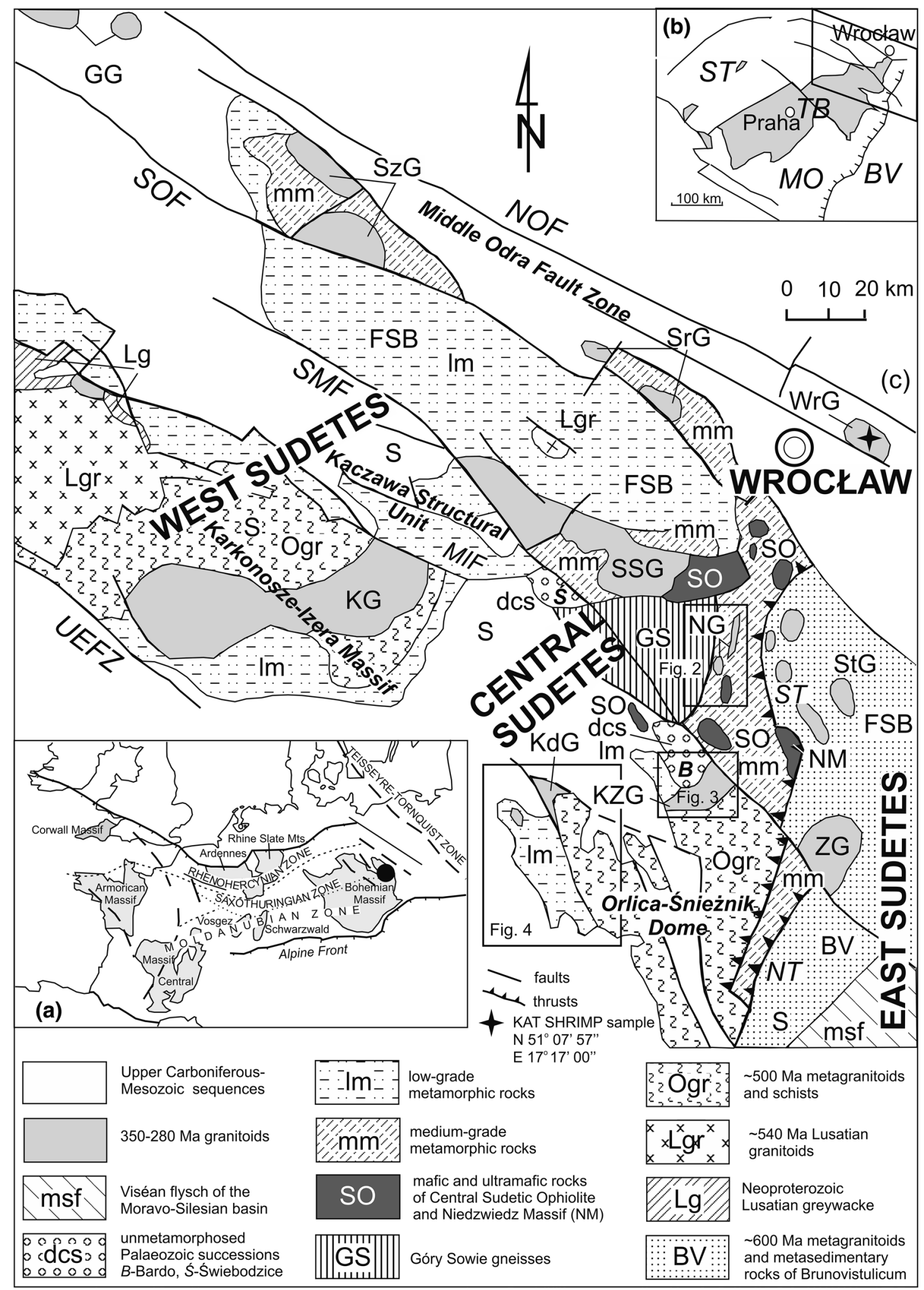

Schulmann and Gayer 2000), tectonic activity in the West and Central Sudetes was dominated by strike-slip movements along major faults/shear zones, exhumation of deeper crustal units and intense granitic plutonism (Mazur et al.
2006). At that time, dextral strike-slip movements occurred along the boundary between the Nové Město Unit and the Orlica-Śnieżnik Massif (Mazur et al. 2005), and sinistral displacements took place along the NNE-SSW-striking 


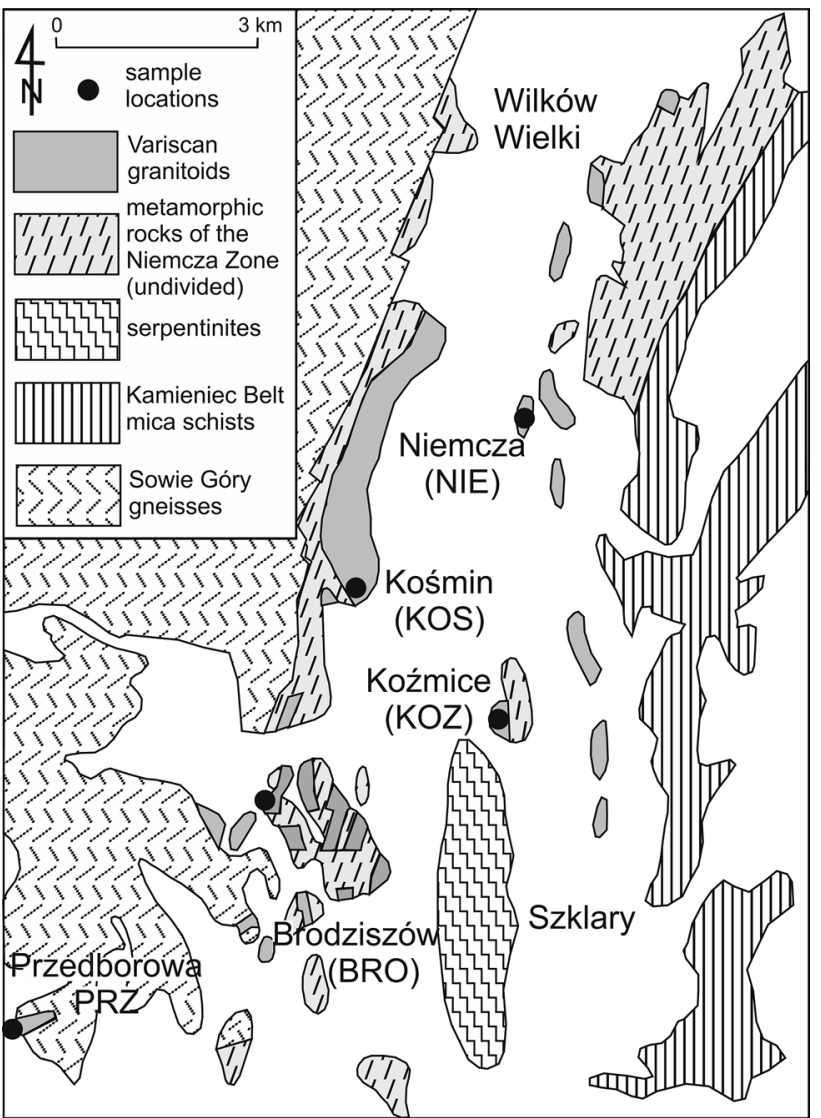

Fig. 2 Geological sketch map of the Niemcza Zone and adjacent areas, based on map from Lorenc (1998, and references therein), and modified by the authors after the map of Mazur and Puziewicz (1995, and references therein)

Niemcza Shear Zone (Mazur and Puziewicz 1995) and the NE-SW trending Skrzynka Shear Zone (e.g. Cymerman 1996). The three strike-slip zones mentioned are accompanied by small granitoid bodies dated at 350-340 Ma and c. 325 Ma (Oliver et al. 1993; Pietranik et al. 2013; Mikulski et al. 2013; Mikulski and Williams 2014; Białek and Werner 2004; Białek 2014, and new data presented hereafter).

Plutons of similar ages as those from the CS occur also within the MOFZ, between the South and North Odra faults (Dörr et al. 2006; Fig. 1). Deformational structures of some of the Odra granitoids (Oberc-Dziedzic et al. 1999; Dörr et al. 2006) suggest a likely strike-slip character of the South Odra Fault (Fig. 1c).

The Middle Odra Fault Zone

The Middle Odra Fault Zone (Fig. 1c) forms an elongated, NW-SE trending horst, c. $200 \mathrm{~km}$ long and $20 \mathrm{~km}$ wide, entirely concealed under Cainozoic deposits. This horst is composed of amphibolite and greenschist facies metasedimentary and metabasic rocks, relatively older and of higher

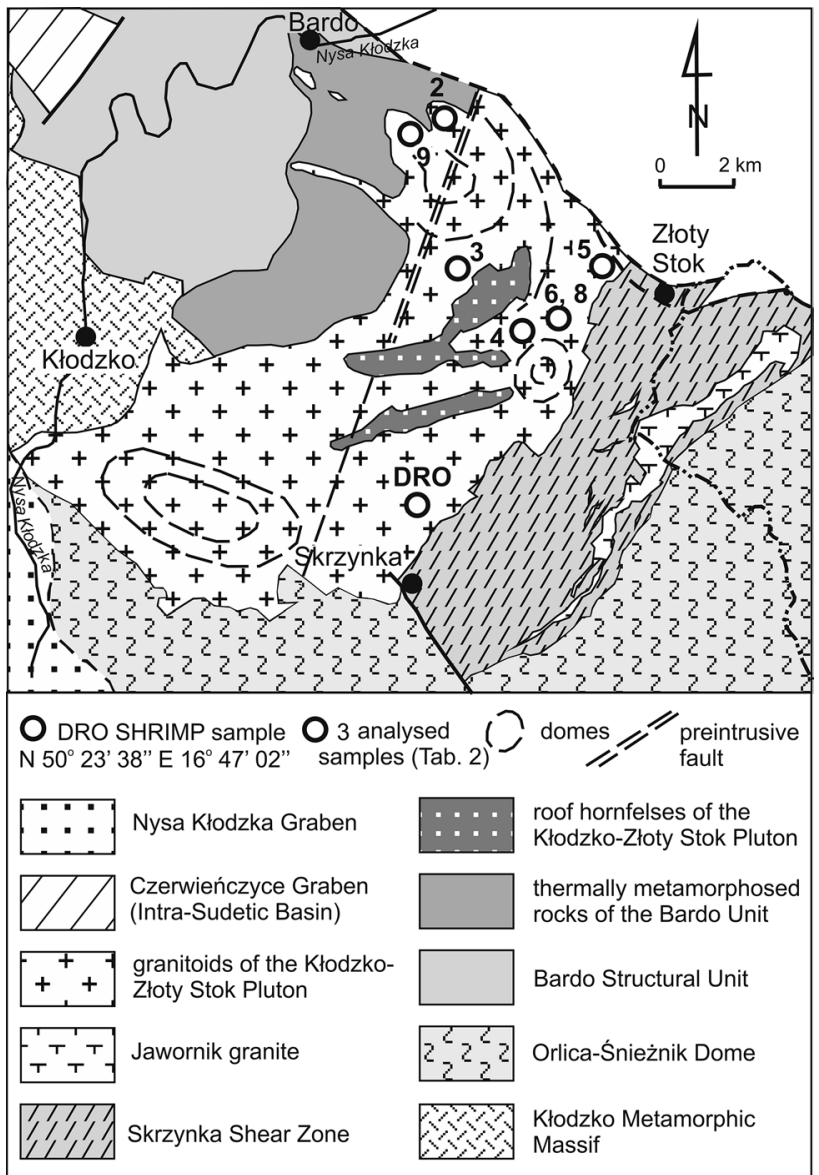

Fig. 3 Geological map of the Kłodzko-Złoty Stok Granitoid Massif, after Wierzchołowski (1976); position of domes according to Wojciechowska (1975)

metamorphic grade compared with those in the two adjacent areas: the West Sudetes (in its Fore-Sudetic part) to the SW and the Wielkopolska Phyllite Unit (Żelaźniewicz et al. 2003) to the NE. The metamorphic rocks are pierced by granitoids.

The position of the MOFZ in the European Variscides was discussed in detail by Dörr et al. (2006). Żelaźniewicz et al. (2003) interpreted this zone as a collisional transpressive suture between the Saxothuringia and Wielkopolska terranes (both being members of the Armorican Terrane Assemblage; Tait et al. 1997).

\section{The Niemcza Shear Zone}

The NNE-SSW-striking Niemcza Shear Zone, $42 \mathrm{~km}$ long and $5 \mathrm{~km}$ wide, separates the Góry Sowie Gneiss Massif to the west from the Kamieniec Metamorphic Belt to the east. To the north, it is bordered by the Central Sudetic Ophiolite (Ślęża Ophiolite) and, to the south, by the Marginal Sudetic Fault (Fig. 1c). 


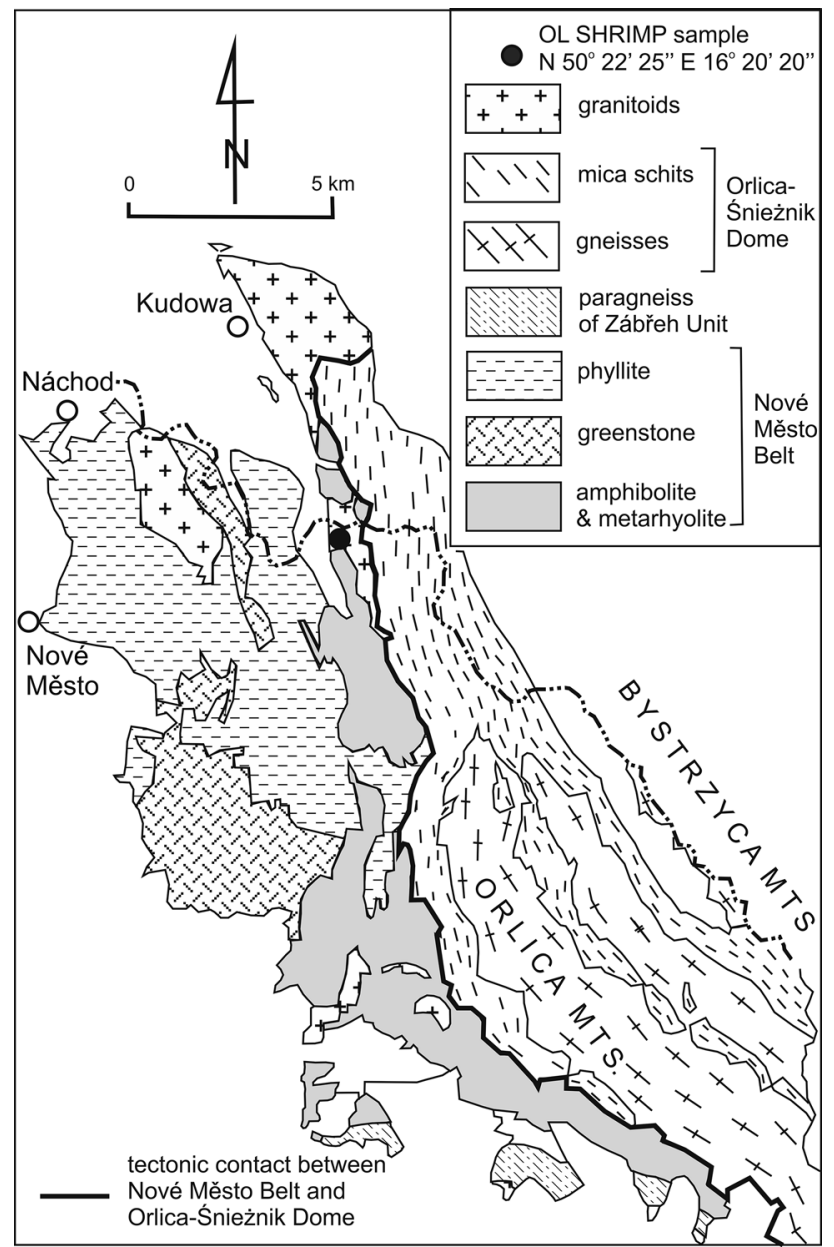

Fig. 4 Geological map of the boundary zone between the TepláBarrandian and Moldanubian units in the Sudetes after Mazur et al. (2005)

According to the early concepts of Finckh (1925), Bederke (1929) and Meister (1932), followed by Dziedzicowa (1963, 1987) and Franke and Żelaźniewicz (2000), the rocks of the Niemcza Zone were derived from greywackes. However, Scheumann (1937) suggested that the Niemcza rocks were mylonitized Góry Sowie gneisses. The latter view was shared by Mazur and Puziewicz (1995).

The Niemcza Shear Zone comprises mylonitized Góry Sowie gneisses. Amphibolites, quartz-graphite schists, mica schists form intercalations within the mylonites. Two fragments of the Central Sudetic Ophiolite: the Szklary Serpentinite Massif and the Braszowice-Brzeźnica Gabbro-Serpentinite Massif are enclosed within the Niemcza Zone. The mylonites are intruded by conformable sheets of granitoids.

The mylonites contain porphyroclasts of plagioclase $\left(\mathrm{An}_{20-30}\right)$, garnet and cordierite. Cordierite occurs also as younger porphyroblasts predating the intrusion of granitoids (Dziedzicowa 1987). The matrix is composed of quartz and plagioclase, accompanied by syndeformational biotite and fibrolite in high-temperature mylonites, or muscovite and chlorite in low-temperature varieties (Mazur and Puziewicz 1995). The lack of substitution between the high- and low-temperature mineral assemblages of the mylonites suggests that the mylonitization took place under variable conditions, simultaneously, in different parts of the Niemcza Shear Zone (Mazur and Puziewicz 1995).

The penetrative foliation of the mylonites is parallel to the foliation of the Gory Sowie gneisses and to the lithological boundaries inside the Niemcza Shear Zone. The shear sense indicators point to non-coaxial deformation and a sinistral sense of shear. The mylonitization was followed by dextral shearing documented by the igneous fabric of the Koźmice granodiorite (Puziewicz 1992; Mazur and Puziewicz 1995; Cymerman and Piasecki 1994).

The eastern boundary of the Niemcza Shear Zone with the Kamieniec Metamorphic Belt is less distinct than its western boundary with the Góry Sowie Massif, due to mesoscopic similarity of the gneiss-derived mylonites and the mylonitized mica schists to the east. The main difference between them is the An content in plagioclase (oligoclase $\mathrm{An}_{20-30}$ in the mylonites versus albite in the mica schists) (Mazur and Puziewicz 1995) and, additionally, the presence of staurolite in the mica schists.

The sinistral strike-slip displacements in the Niemcza Shear Zone were coeval with the $\mathrm{D}_{3}$ event that involved WSW-directed extension in the adjacent Kamieniec Metamorphic Belt (Mazur and Józefiak 1999) resulting in rapid decompression. This is documented by andalusite growth, not only in the Kamieniec mica schists, but also in the gneisses at the eastern margin of the Góry Sowie Massif (Dziedzicowa 1987; Mazur and Józefiak 1999; Nowak 1998).

\section{The Złoty Stok-Skrzynka Shear Zone}

The Złoty Stok-Skrzynka Shear Zone, trending NNE-SSW to NE-SW, approximately $12 \mathrm{~km}$ long and $4 \mathrm{~km}$ wide, separates the Kłodzko-Złoty Stok Granitoid Massif in the NW, from the metamorphic rocks of the Orlica-Śnieżnik Dome in the SE (Fig. 3).

The Skrzynka Shear Zone exposes blastomylonites, mylonites and cataclasites derived from the Orlica-Śnieżnik gneisses and associated quartzo-feldspathic schists (Kozłowska-Koch 1973; Dumicz 1988). These rocks show penetrative, NNE-SSW-trending and steeply dipping foliation, parallel to the zone boundaries, as well as a subhorizontal to shallow SW-plunging mineral stretching lineation (Dumicz 1988; Cymerman 1996; Murtezi 2006). The main deformation in the shear zone was a sinistral ductile strike-slip non-coaxial shear (Cymerman 1996). The rocks of this shear zone were intruded by the Jawornik granitoids (Fig. 3). 
The metamorphic rocks of the Złoty Stok-Skrzynka Shear Zone underwent two high-temperature, low-pressure thermal events. The first event took place after the mylonitization and before the intrusion of the Jawornik granitoids, and produced cordierite + andalusite paragenesis, subsequently replaced by cordierite + sillimanite assemblage. The growth of these minerals was not related to the proximity of granitoids (Kozłowska-Koch 1973). The second event was caused by the thermal influence of the Kłodzko-Złoty Stok intrusion. It affected metamorphic rocks at the contact with granitoids and transformed them into hornfelses with andalusite, cordierite and sillimanite (Kozłowska-Koch 1973).

\section{The Nové Město-Orlica-Śnieżnik Shear Zone}

The Nové Mĕsto-Orlica-Śnieżnik Shear Zone, between the Neoproterozoic? phyllite-amphibolite Nové Město Unit in the west, and the orthogneisses (with Lower Ordovician protolith) and Neoproterozoic? mica schists of the OrlicaŚnieżnik Dome in the east (Fig. 4), has been considered as the boundary between the Teplá-Barrandian and the Moldanubian terranes (Mazur et al. 2005). Both the adjacent units recorded a top-to-the SE thrusting of the Nové Mĕsto rocks and an early telescoping of both terranes within a nappe pile. This overthrust contact was reworked by dextral shear, resulting in a $1-2-\mathrm{km}$-wide shear zone with a relative vertical displacement of both units leading to tectonic juxtaposition of the hot, middle crustal OrlicaŚnieżnik rocks with the colder, upper-crustal Nové Město Unit (Mazur et al. 2005).

In the Nové Město Unit (Fig. 4), the metamorphic grade increases from greenschist facies in the west to amphibolite facies along its boundary with the Orlica-Śnieżnik Dome. In the Orlica-Śnieżnik Unit and in the contact shear zone, amphibolite facies metamorphic conditions were attained (Mazur et al. 2005, 2006; Ilnicki 2013). The metamorphic isograds are roughly parallel to the boundary with the Orlica-Śnieżnik Dome and, also, to the contacts with late-tectonic granitoid intrusions that were emplaced into the boundary shear zone. However, the increase in metamorphic grade was not connected with the thermal influence of these intrusions, which are younger than the shear zone (Mazur et al. 2005), and are too small to produce the $>2-\mathrm{km}$-wide thermal aureole (in so far as the surface outcrops reflect their true extent at depth).

\section{Granitoids of the Central Sudetes and of the Middle Odra Fault Zone}

In the Sudetes and in the Middle Odra Fault Zone, numerous Variscan granitoid intrusions occur (Fig. 1c). The largest composite granitoid plutons, the Karkonosze Pluton and the Strzegom-Sobótka Pluton, are situated in the West Sudetes. The granitoids of the Karkonosze Pluton are dated by the ID-TIMS method at $312 \mathrm{Ma}$; the earlier reported SIMS (SHRIMP) zircon data are scattered mainly between ca. 322 and 302 (e.g. Kryza et al. 2012, 2014). The granitoids of the Strzegom-Sobótka were emplaced between $\sim 305$ and $295 \mathrm{Ma}$ (SHRIMP U-Pb method, Turniak et al. 2014; for earlier results, see Turniak et al. 2005; Mazur et al. 2007).

The East Sudetes, in contrast, abound in small intrusions of Variscan granites, tonalites and quartz diorites that crop out in the Strzelin Massif and are hidden under Cainozoic sediments east of this massif. These granitoids are dated at 301-291 Ma (Turniak et al. 2006; zircon Pb-evaporation method); $295 \mathrm{Ma}$ (Pietranik and Waight 2008; Rb-Sr mineral and WR isochron); 324-283 Ma (Oberc-Dziedzic et al. 2010a, 2013; Oberc-Dziedzic and Kryza 2012: SHRIMP $\mathrm{U}-\mathrm{Pb}$ zircon method). South of the Strzelin Massif, the Variscan granitoids form the relatively large Žulová Pluton $(291 \pm 5 \mathrm{Ma} ; 292 \pm 4$ Ma, LA-ICP-MS U-Pb zircon dating; Laurent et al. 2014) (Fig. 1c).

The oldest granitoids, c. 350-330 Ma in age, represented by granites, granodiorites, tonalites and diorites, are found in the CS and in the MOFZ. The Bielice tonalite sill in the Staré Město Belt, at the Variscan transpressive boundary between the Moldanubian and Brunovistulian zones, has a similar age of $339 \pm 7 \mathrm{Ma}\left({ }^{207} \mathrm{~Pb} /{ }^{206} \mathrm{~Pb}\right.$ single zircon evaporation technique; Parry et al. 1997).

General petrographic characteristics of the granitoids, compiled from published papers, are shown in Table 1.

The Middle Odra Fault Zone granitoids: the Wrocław granitoids

Granitoids of the MOFZ form four groups of rather small intrusions drilled near Gubin, Szprotawa, Środa Śląska and Wrocław (Oberc-Dziedzic et al. 1999; Fig. 1c). The Gubin and Wrocław granitoids are concealed by thick Lower Permian and Cainozoic deposits, while the Szprotawa and Środa Śląska granitoids are overlain by Cainozoic sediments and only locally by Lower Permian strata. Some of the Odra granitoids show faint magmatic foliation and lineation, whereas the Środa Śląska (Przedmoście) granitoids are intensively deformed under ductile conditions (ObercDziedzic et al. 1999).

The Wrocław granitoids, represented by granodiorite and quartz monzodiorite (Table 1), are known from two boreholes: Katna 1 (at a depth of 1660.0-1791.3 m below the earth surface) and Chrzastawa 1 (at a depth of 1470.0 $1538.7 \mathrm{~m}$ ), c. $15 \mathrm{~km}$ EEN and EES of the Wrocław city centre, respectively (Fig. 1c). Subcrops of these granitoids are c. $1.5 \mathrm{~km}$ downthrown relative to subcrops of 


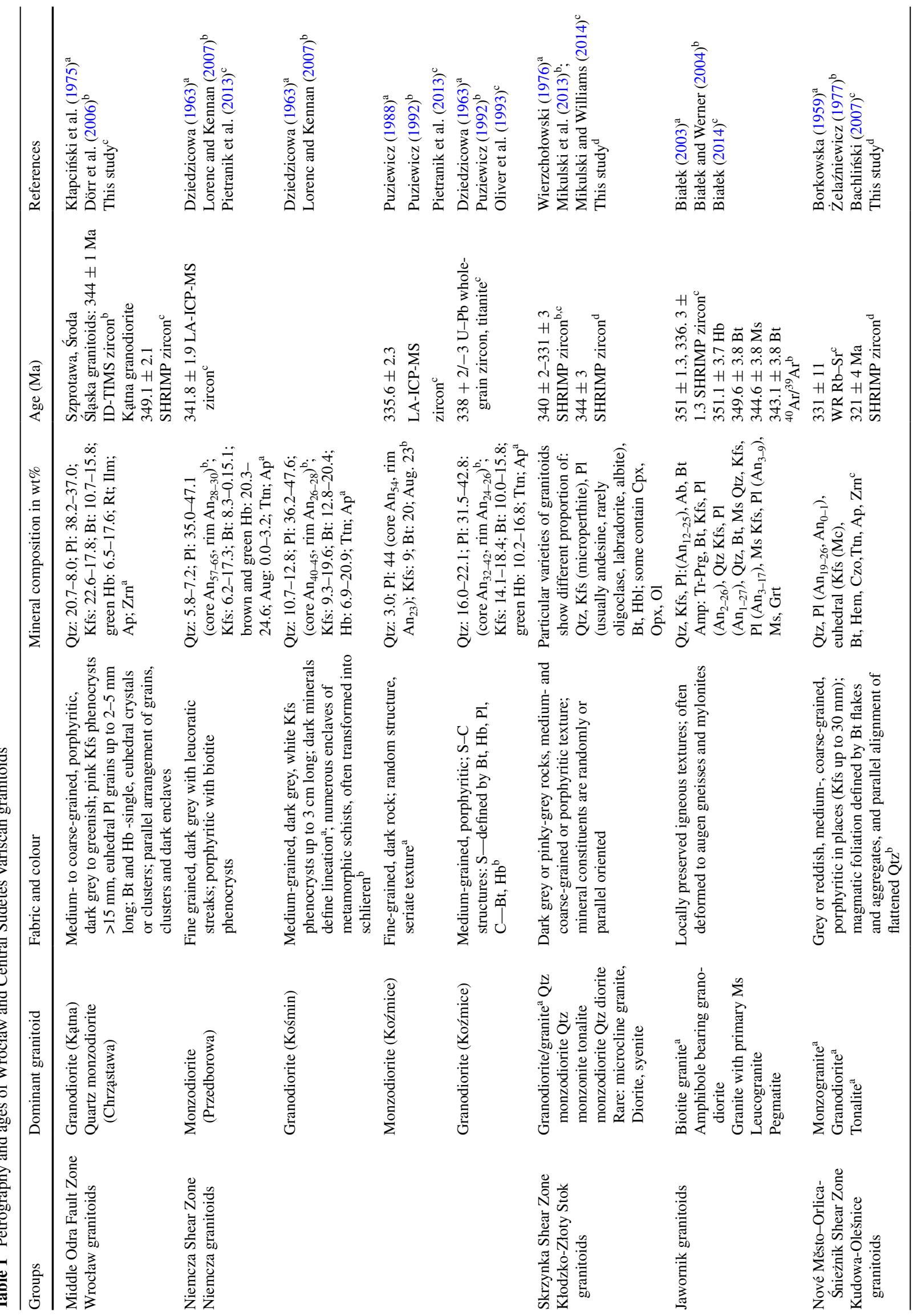


the Sroda Ślaska and Szprotawa granitoids. The size, shape and thickness of the Wrocław granitoid body are unknown.

In the Katna borehole, the granodiorite is overlain by dark, fine-grained, partly migmatitic gneisses (1357.0$1660.0 \mathrm{~m}$ ) containing relics of pinite pseudomorphs after cordierite. Textural evidence suggests that the growth of cordierite and the migmatization of the gneisses preceded the intrusion of the granodiorite (Oberc and Oberc-Dziedzic 1978).

\section{The Niemcza Shear Zone granitoids}

Granitoids of the Niemcza Shear Zone (Fig. 2; Table 1) are subdivided into two main varieties: 1. medium-grained porphyritic granitoids (the Kośmin type): granodiorites, quartz monzonites, quartz monzodiorites and rare granites; they occur throughout the Niemcza Zone in numerous, relatively small, $1.5 \mathrm{~m}$ to c. $100 \mathrm{~m}$, sheet-like bodies; 2. fine-grained dioritoids, quartz syenite, vaugnerite, locally tonalites (the Przedborowa type), with rare enclaves (Dziedzicowa 1963; Mazur and Puziewicz 1995; Lorenc and Kennan 2007); the latter form a few bodies at the western and eastern margins of the Niemcza Zone. The contacts between the two varieties are sharp (Lorenc and Kennan 2007).

The medium-grained granitoids show magmatic foliation and lineation, both broadly concordant with the foliation and lineation in the surrounding metamorphic rocks (Dziedzicowa 1963). The Koźmice granodiorite (Fig. 2) displays structures that indicate continuous deformation from magmatic to subsolidus stage. The $\mathrm{S} / \mathrm{C}$ structures point to dextral shearing during the subsolidus stage (Puziewicz 1992).

The fine-grained monzodiorite from Koźmice, although older than the granodiorites, does not show any mesoscopic foliation and lineation (Puziewicz 1992). However, studies of anisotropy of magnetic susceptibility (AMS) revealed that a subhorizontal magnetic lineation occurs in the majority of medium-grained granodiorite bodies and in the Koźmice monzodiorite (Werner 2002). These results confirm that the granitoids in the Niemcza Shear Zone were emplaced as syntectonic magmas.

The granodiorites contain numerous enclaves of metamorphic schists arranged broadly parallel to the granodiorite foliation. Many of them are transformed into schlieren. The complete transformation of the xenoliths apparently caused the observed variability of the mineral and chemical composition of the medium-grained granitoids (Lorenc and Kennan 2007).

The Kośmin granodiorite were interpreted to have crystallized from a magma within a temperature range of 850$730{ }^{\circ} \mathrm{C}$ and pressure of $4 \pm 1 \mathrm{kbar}$ (Puziewicz 1992), i.e. at a depth of $\sim 16-18 \mathrm{~km}$.
The Złoty Stok-Skrzynka Shear Zone granitoids: the Kłodzko-Złoty Stok granitoids

The Kłodzko-Złoty Stok Pluton (Figs. 1, 3) is the largest granitoid intrusion $\left(120 \mathrm{~km}^{2}\right)$ in the CS. To the south-east, the massif is bordered by orthogneisses $(\sim 500 \mathrm{Ma}$, Turniak et al. 2000) and mica schists (c. 560-490 Ma, Mazur et al. 2012) of the Orlica-Śnieżnik Dome, and by the rocks of the Złoty Stok-Skrzynka Shear Zone (Figs. 1c, 3). To the west, the massif intrudes the rocks of the Kłodzko Metamorphic Unit (Neoproterozoic-Middle/Upper Devonian, Mazur et al. 2006), and to the NW, the Palaeozoic (including Lower Carboniferous) sedimentary rocks of the Bardo Unit. The north-eastern part of the massif is truncated by the Sudetic Marginal Fault (Bederke 1922).

The Kłodzko-Złoty Stok Massif is composed mainly of granodiorite, with transitions to granite, quartz monzodiorite, quartz monzonite and tonalite. Less abundant are monzodiorite, quartz diorite and monzonite, whereas microcline granite, diorite and syenite are scarce (Wierzchołowski 1976; Table 1).

The Kłodzko-Złoty Stok granitoids show a magmatic foliation defined by accumulations of biotite and hornblende, which delineates several dome structures in the intrusion (Wojciechowska 1975; Fig. 3). Mafic enclaves of tonalite, diorite, quartz diorite and mela-gabbro abundant throughout the pluton are interpreted in terms of mingling of acid and basic magmas (Lorenc 1994). Apart from the mafic enclaves, the granitoids of this massif contain also xenoliths of country rocks, mostly representing roof pendant hornfelsed rocks.

The Kłodzko-Złoty Stok Pluton and its country rocks are cut by dykes of pegmatite, aplite, porphyritic microgranodiorite and lamprophyres (spessartite and vogesite) (Wierzchołowski 1976, 1977, 2003; Awdankiewicz 2007).

The contact with the country rocks is distinctly intrusive with a well-defined thermal aureole. The highest temperatures of $750{ }^{\circ} \mathrm{C}$ are recorded in rocks at the very contact and within the roof pendants. The width of the thermal aureole was estimated as several hundred metres within the metamorphic rocks of the Orlica-Śnieżnik Dome (Bagiński 2002), and c. $2200 \mathrm{~m}$ within sedimentary rocks of the Bardo Unit, where the temperature may have reached $500-400{ }^{\circ} \mathrm{C}$ (Wierzchołowski 1976; Bagiński 2002). However, temperatures estimated using the Conodont Alteration Index (CAI) indicate that the areal extent of the thermal influence of the intrusion on the sedimentary rocks of the Bardo Unit was greater than suggested by earlier estimates (Haydukiewicz 2002).

The Złoty Stok-Skrzynka Shear Zone granitoids: the Jawornik granitoids

The Jawornik granitoids, represented by biotite granite, amphibole-bearing granodiorite, granite with primary 
muscovite, leucogranite and pegmatite (Burchart 1960; Białek 2003; Table 1), form a set of NNE-SSW-aligned small intrusions, interpreted mainly as sills and, subordinately, dykes in the host rocks of the Skrzynka Shear Zone (Białek and Werner 2002).

The granitoids have been variably deformed during magmatic to submagmatic stages, with a minor solid-state overprint. The granitoid foliation, NNE-SSW-trending and moderately to steeply dipping towards $\mathrm{W}$ and $\mathrm{E}$, is parallel to the elongation of the magmatic bodies. The foliation defined by the anisotropy of magnetic susceptibility shows a good correlation with the mesoscopic tectonic foliation at the outcrop scale. The NE-SW trend of the gently plunging magnetic lineation is attributed to magma flow during emplacement (Białek and Werner 2002).

The Jawornik granitoids probably crystallized at 660 $730{ }^{\circ} \mathrm{C}$ and under pressure of $5.5 \mathrm{kbar}$, corresponding to a depth of 18-23 km (Białek 2003).

The Nové Město-Orlica-Śnieżnik Shear Zone granitoids: the Kudowa-Olešnice granitoids

The Kudowa-Olešnice Massif is an N-S elongated, 15-kmlong and 1.5-(in the $\mathrm{S}$ ) to $5-\mathrm{km}$ (in the $\mathrm{N}$ )-wide granitoid intrusion (Fig. 4). The northern part of the massif is composed of grey, medium-grained granodiorite, and red, fineto medium-grained granodiorite (Białek 2006). The southern, narrow part of the massif is mainly composed of older granodiorite and tonalite.

According to Żelaźniewicz (1977), the granitoids of the Kudowa-Olešnice Massif show a distinct magmatic foliation defined by parallel alignment of biotite and flattened quartz grains deformed into mosaic aggregates due to protoclasis. The orientation of the foliation indicates that the larger and younger northern part of the massif has a loaf-like shape and is floored and roofed by mica schists (the Stronie Formation) in the western part of the OrlicaŚnieżnik Dome. In this part of the pluton, magma was delivered through a rather narrow channel, NE of Kudowa, marked by the steeply dipping planar structures and the occurrence of enclaves (Fig. 4). The older granitoids in the south form a number of sheets (up to $500 \mathrm{~m}$ thick), parallel to the foliation of metamorphic rocks, in the discontinuity zone separating the Nové Město and Orlica-Śnieżnik Dome units (Żelaźniewicz 1977).

\section{Methods used}

Petrography, geochemistry and tectonics of the Central Sudetes granitoids have been studied earlier by many authors, and their results are compiled and discussed hereafter, together with our new data on geochemistry, $\mathrm{Sr}-\mathrm{Nd}$ radiogenic isotope characteristics and U-Pb SHRIMP zircon ages from three samples of selected granitoids.

Fifteen samples of granitoids have been analysed in the ACME Analytical Laboratories Ltd, Canada, for major, trace and rare earth elements, using combined ICP-OES and ICP-MS techniques.

The same samples were analysed at Université Blaise Pascal, Clermont-Ferrand, for Sm-Nd isotopes, following the procedure described by Pin and Santos Zalduegui (1997). The initial ${ }^{143} \mathrm{Nd} /{ }^{144} \mathrm{Nd}$ ratios are expressed as $\varepsilon \mathrm{Nd}_{\mathrm{i}}$ values, corrected for in situ decay of ${ }^{147} \mathrm{Sm}$, assuming an age of $340 \mathrm{Ma}$ for the Wrocław, Niemcza and Kłodzko-Złoty Stok granitoids, and $320 \mathrm{Ma}$ for the Kudowa (Olešnice) granite. The model ages are calculated relative to the depleted mantle model of De Paolo (1981a, b).

$\mathrm{Rb}$ and $\mathrm{Sr}$ concentrations were determined at Ecole Nationale des Mines d'Alès (France) by wavelength dispersive X-ray fluorescence spectrometry with a Philips PW 1400 sequential spectrometer. The analytical procedure followed the method described by Harvey and Atkin (1981), with a calibration using USGS and CRPG international reference rocks. The results were the average of six replicate measurements of each pressed powder pellet, with relative standard deviation better than $1 \%$. Sr isotopic compositions were measured using an upgraded VG54 E thermal ionization mass spectrometer, after chemical separation using standard cation exchange techniques (see Pin et al. 1990 for details).

Three samples, one from the Kłodzko-Złoty Stok granodiorite, one from the Wrocław granite and one from the Kudowa granite, have been selected for SHRIMP zircon dating. Details of the SHRIMP analytical procedures are given in Online Resource 1.

\section{Geochemistry of granitoids of the Central Sudetes and of the Middle Odra Fault Zone}

\section{Major elements}

The CS and the Wrocław granitoids are predominantly magnesian (apart from a few samples of the KłodzkoZłoty Stok granitoids; Fig. 5a, c, e, g), and alkali-calcic, calc-alkalic, exceptionally calcic and alkalic rocks (Fig. 5b, d, f, h). In comparison, most of the granitoids from the Strzegom-Sobótka and Strzelin massifs (West and East Sudetes, respectively) represent both magnesian and ferroan types and belong to the calc-alkalic type (Domańska-Siuda 2007; Oberc-Dziedzic et al. 2013). The majority of the CS and Wrocław granitoids are high to very high potassic (Fig. 6), and both metaluminous and peraluminous (Table 2). 
Fig. 5 Classification diagrams (Frost et al. 2001) for the Central Sudetes granitoids. Analytical data: a, b Sachanbiński (1980); c, d Dziedzicowa (1963); Puziewicz (1992); Pietranik et al. (2013); e, f Bachliński and Bagiński (2007) and references therein; $\mathbf{g}, \mathbf{h}$ Bachliński (2007)
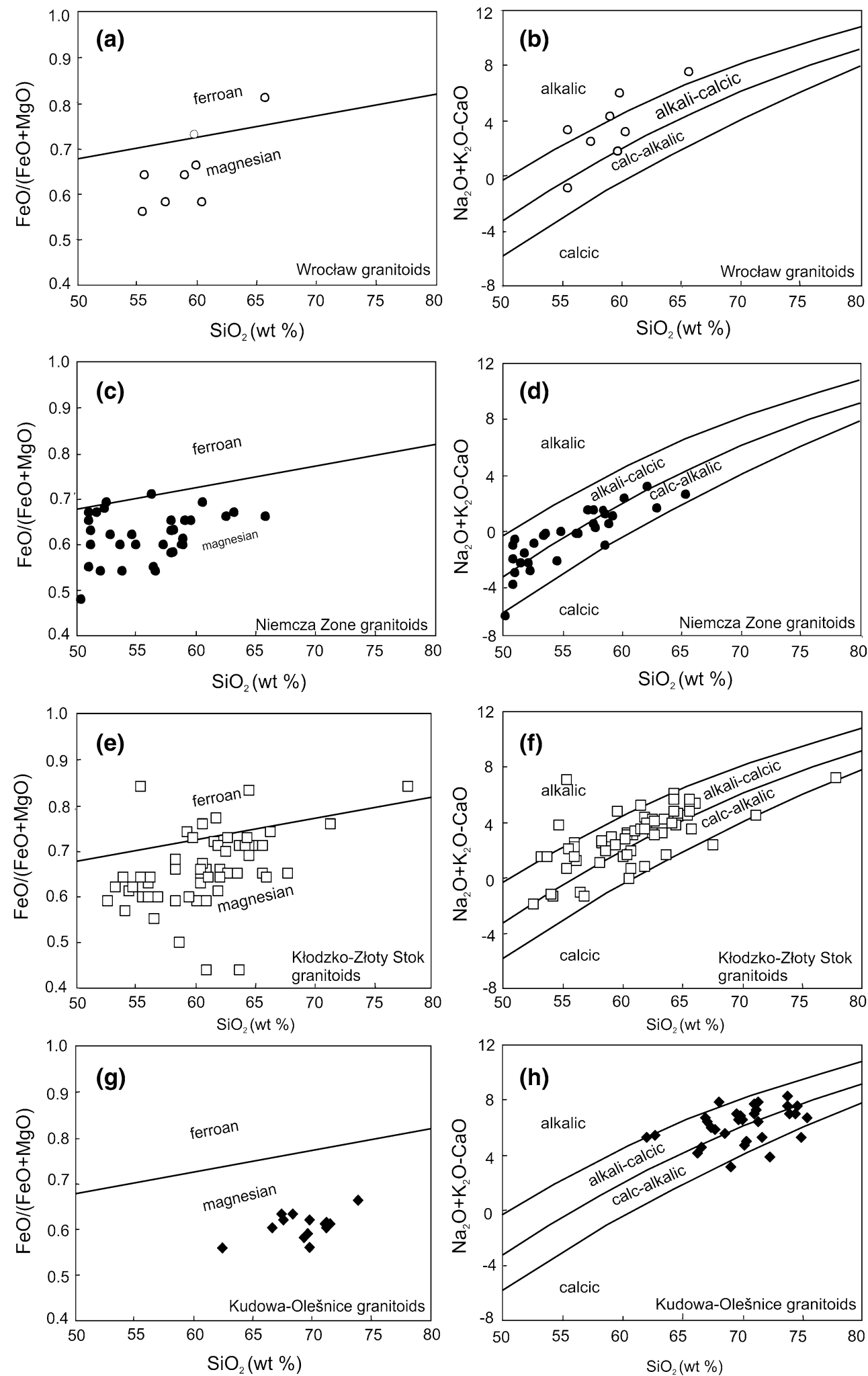

Trace elements

The chondrite-normalized multi-element diagrams are characterized by distinct negative $\mathrm{Nb}$ and $\mathrm{Ti}$ anomalies
(Fig. 7a, c, e). Negative $\mathrm{P}$ anomaly is well visible in the Olešnice granodiorite and in some varieties of the KłodzkoZłoty Stok and Niemcza granitoids. At variance with what is observed in the Strzelin Massif (Oberc-Dziedzic et al. 


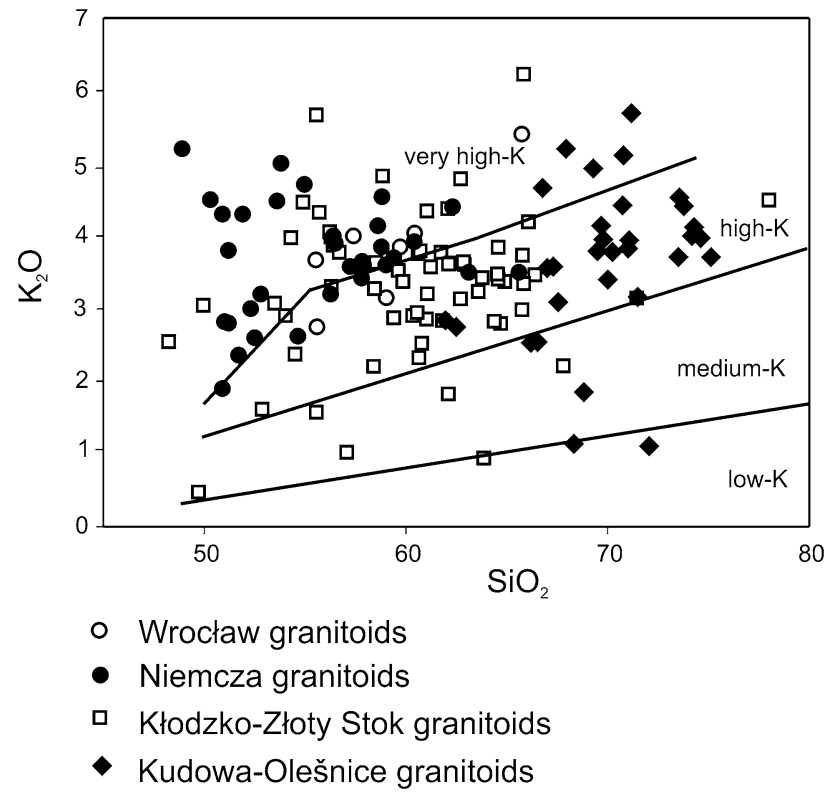

Fig. 6 Relationships between the $\mathrm{SiO}_{2}$ and $\mathrm{K}_{2} \mathrm{O}$ contents in granitoids of the Central Sudetes and Middle Odra Fault Zone. The boundaries between low-, medium-, high- and very high-K rocks after Pecerrillo and Taylor (1976). Analytical data: Table 2, this study; Sachanbiński (1980); Dziedzicowa (1963); Puziewicz (1992); Pietranik et al. (2013); Bachliński and Bagiński (2007) and references therein; Bachliński (2007)

2010a, 2013), there is no very strong negative $\mathrm{Sr}$ anomaly in the CS and Wrocław granitoids (Fig. 7a, c, e). The relatively weak $\mathrm{Sr}$ anomaly suggests either that plagioclase fractionation played a minor role in the igneous evolution, or that different source material and resulting partial melts were involved in the studied granitoids, when compared to those of the Strzelin Massif. Worth noticing is that the OL sample displays a HREE depletion which might reflect a magma extracted from a relatively deep crustal source containing residual garnet; this would be in fair agreement with $\mathrm{Sr}-\mathrm{Nd}$ radiogenic isotopes (Bachliński 2007) which point to an almost purely crustal source for this granite.

The multi-element diagrams for the granitoids of Katna, Olešnice and Niemcza show distinct negative Ta anomaly (Fig. 7a, c), similar to that reported from tonalites of the Strzelin Massif (Oberc-Dziedzic et al. 2010a). The Kłodzko-Złoty Stok granitoids show also a negative Ta anomaly, but weaker than in the other samples (Fig. 7e).

The granitoids of Wrocław and of the CS show different total REE concentrations, from 50 to $251 \mathrm{ppm}$ (Table 2; Bachliński 2007). In all studied granodiorites, the (La/ $\mathrm{Yb})_{\mathrm{N}}$ ratios are between 7.9 and 14 (Table 2). A distinctly lower $\mathrm{La}_{\mathrm{N}} / \mathrm{Yb}_{\mathrm{N}}$ ratios observed in pegmatite (3.5) and leucocratic granodiorite of the Kłodzko-Złoty Stok Massif (4.76) (Table 2; Fig. 7f) are associated with lower total REE concentrations and are therefore interpreted to reflect the removal of LREE-enriched accessory minerals such as allanite and/or apatite (as also indicated by the extremely low amount of P left in the pegmatite KLO 9). The chondrite-normalized REE patterns of the CS and Wrocław (Kạtna) granodiorites display distinct, steeply decreasing LREE and HREE segments (Fig. 7f). These patterns are similar to those of tonalites and biotite granites from the Strzelin Massif (Oberc-Dziedzic et al. 2010a, 2013) and clearly different from the REE patterns of the Karkonosze granites (Kryza et al. 2014, and references therein).

In all the CS and the Wrocław granodiorites (except for the highly fractionated pegmatite KLO 9; Fig. 7f), the depth of the $\mathrm{Eu} / \mathrm{Eu}^{*}$ anomalies are broadly similar: 0.610.93 (average 0.7; Table 2; Fig. 7f). These values are also similar to those in the tonalites $(0.62-0.80)$, but lower than those observed in the biotite granites $(0.54-0.64)$ of the Strzelin Massif (Oberc-Dziedzic et al. 2010a, 2013) and in the Karkonosze granites (0.17-0.49) (Kryza et al. 2014). Bearing in mind that negative Eu anomalies in granitoids may either reflect earlier feldspar (mostly plagioclase) fractionation (provided that Eu occurred in significant proportion as the $\mathrm{Eu}^{2+}$ species), or be inherited from source materials, or both, the different anomalies in various Sudetic granitoids might reflect diverse oxidation states of the magmas, variable extent of plagioclase fractionation, different source reservoirs or any combination of these.

$\mathrm{Sm}$ and $\mathrm{Nd}$ isotopes

The ${ }^{147} \mathrm{Sm} /{ }^{144} \mathrm{Nd}$ ratios of the Central Sudetes granitoids are 0.1075 in the Olešnice sample and range from 0.1109 to 0.1430 (Table 3) in the rest of the samples. In general, the average ${ }^{147} \mathrm{Sm} /{ }^{144} \mathrm{Nd}$ ratios are higher in the CS granitoids than in the granitoids of the Strzelin Massif (0.083-0.1136; Oberc-Dziedzic et al. 2010a, 2013), but they are well within the range of values observed in the Karkonosze and Strzegom-Sobótka large intrusions (Pin, unpublished data).

In all the samples of the CS and Wrocław granitoids, the $\varepsilon \mathrm{Nd}_{i}$ values are negative (Table 3 ) reflecting average source materials that were enriched in LREE on a timeintegrated basis. The lowest values of $\varepsilon \mathrm{Nd}_{(t)}-6.3$ is found in the Olešnice granodiorite. Similar values of $\varepsilon \mathrm{Nd}_{331}$, between -7.3 and -6.4 , were obtained by Bachliński (2007) for the Kudowa granitoids. Such strongly negative values document a largely crustal derivation for these bodies. Significantly less negative $\varepsilon \mathrm{Nd}_{(t)}$ values, ranging from -3.2 to -3.9 , characterize the other granitoids, i.e. the Kłodzko-Złoty Stok, Kątna and Niemcza intrusions, with the notable exception of the Przedborowa syenodiorite, having the $\varepsilon \mathrm{Nd}_{(t)}$ values between -1.6 and -2.7 . The mildly non-radiogenic $\mathrm{Nd}$ isotope signatures of the $\mathrm{CS}$ granitoids are similar to those measured in the Karkonosze granite $\left(\varepsilon \mathrm{Nd}_{(t)}=-3.0\right.$ to -3.7 ; Mierzejewski et al. 1994), 


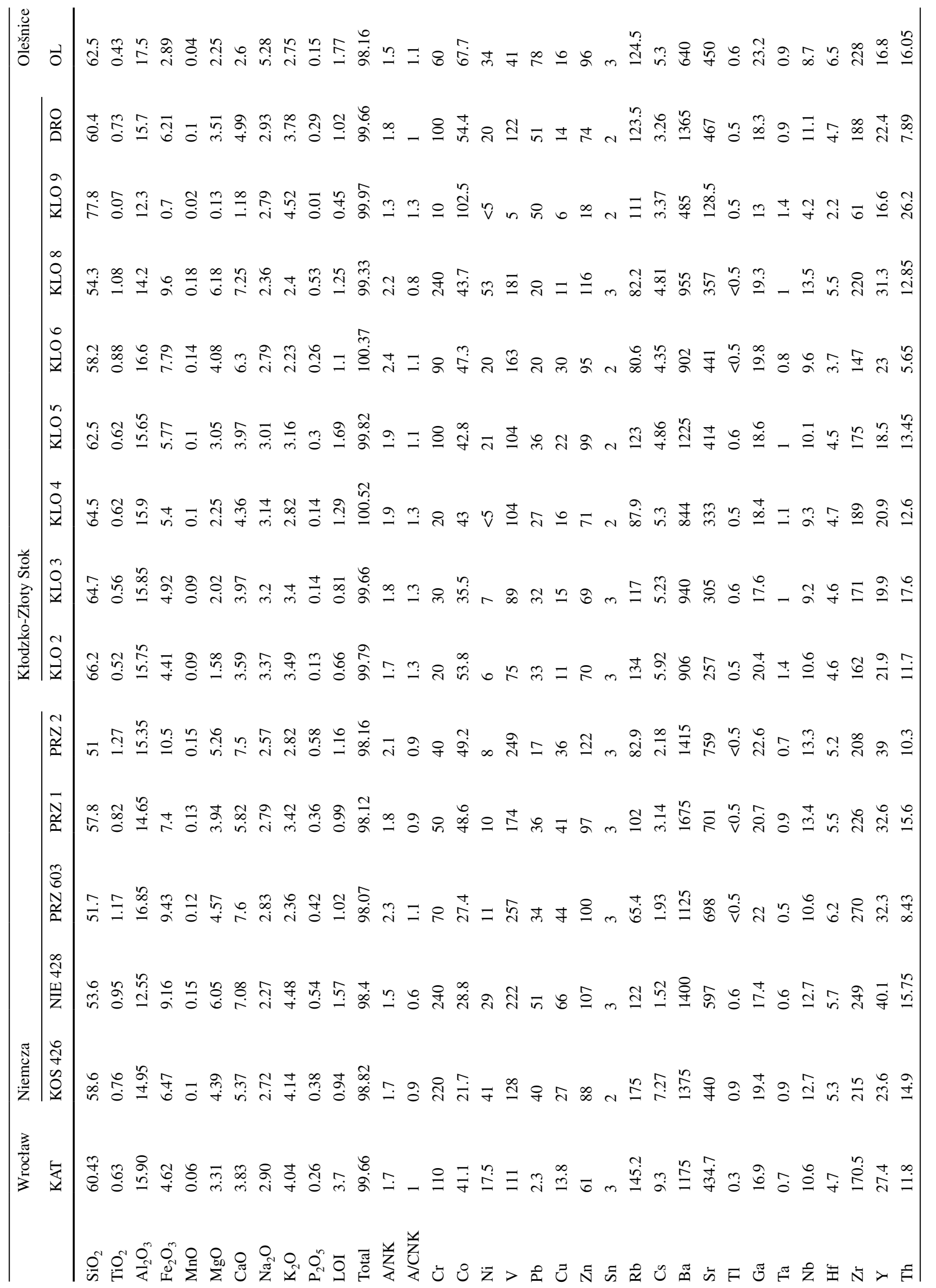




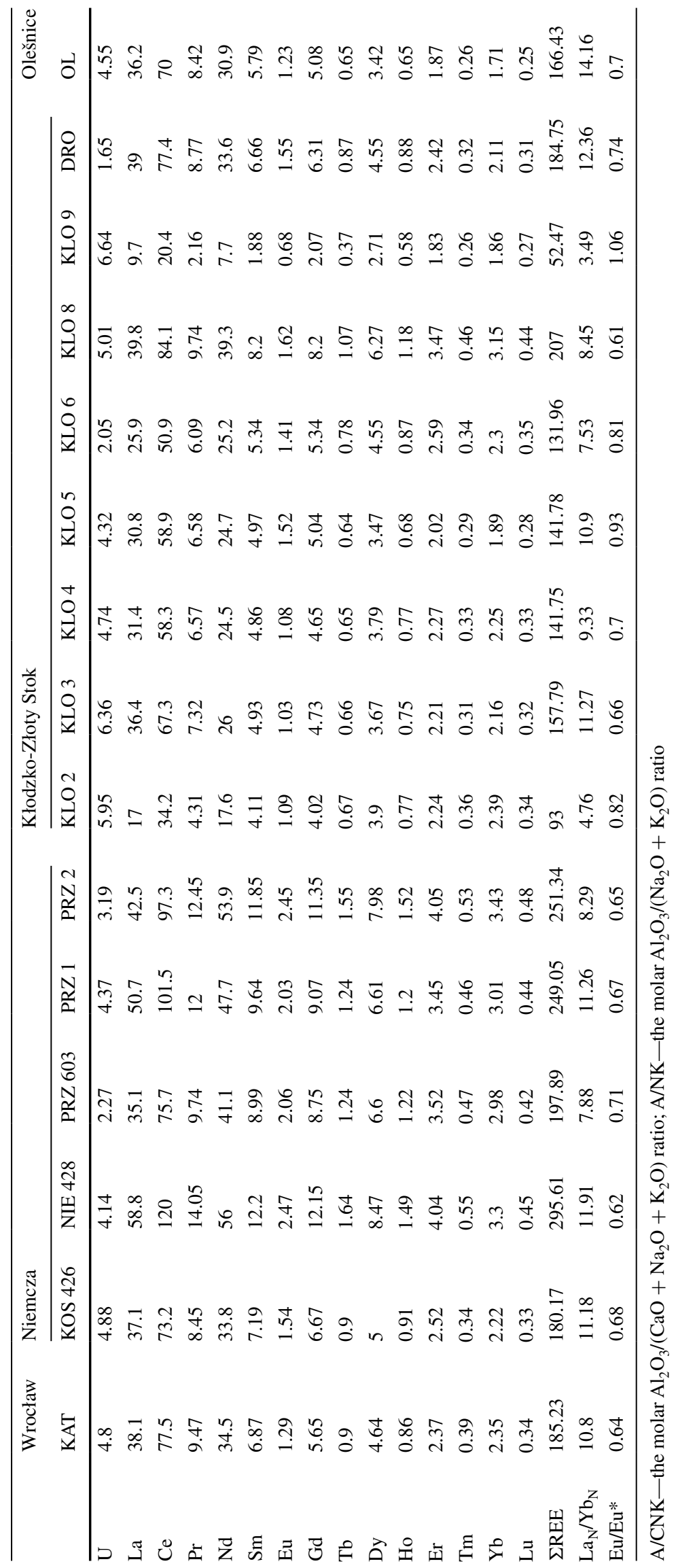



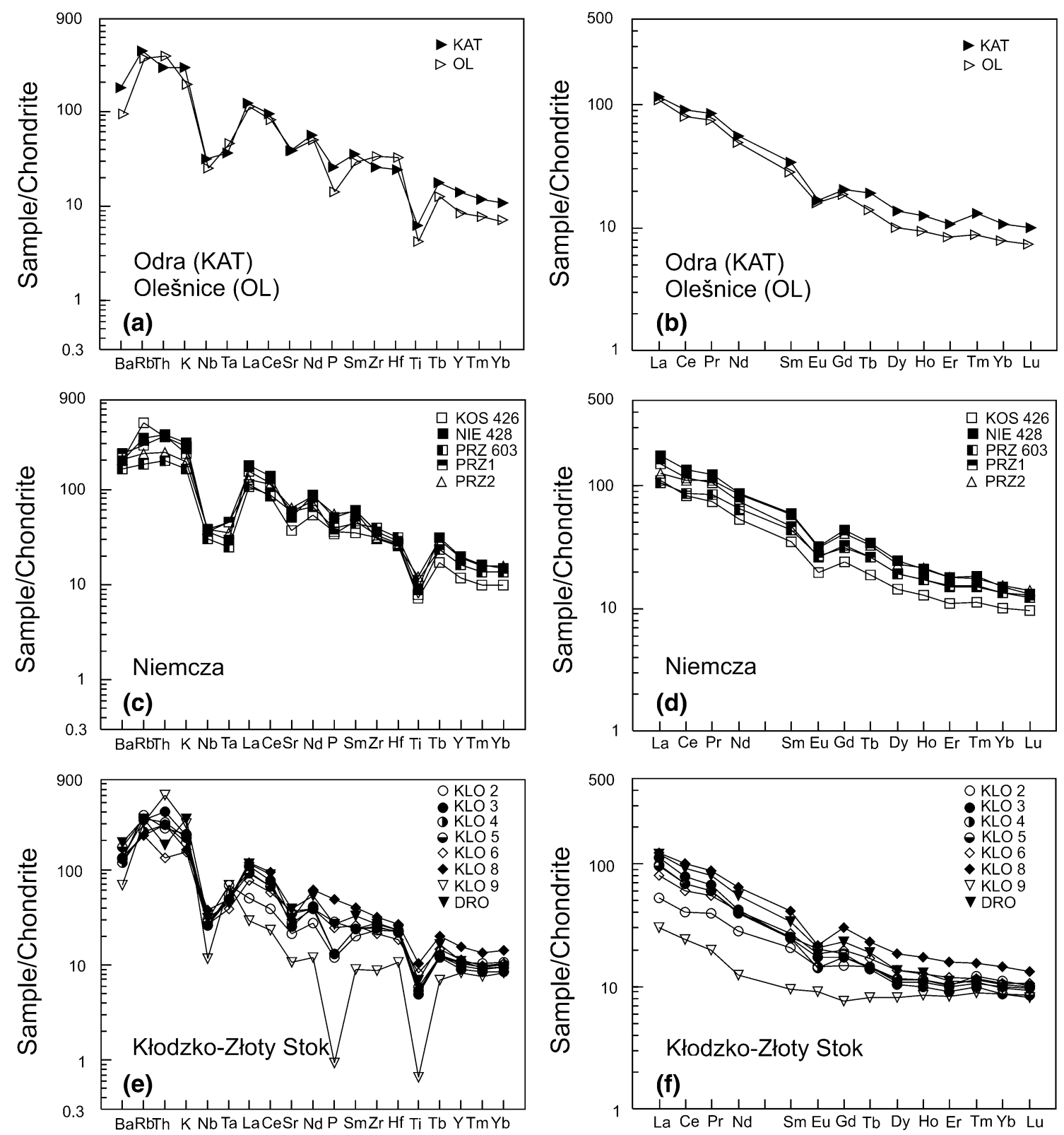

Fig. 7 a, c, e Chondrite-normalized multi-element diagram (normalization values of Thompson 1982), and $\mathbf{b}, \mathbf{d}, \mathbf{f}$ chondrite-normalized REE plot (normalization values of Nakamura (1974), with additions from Haskin et al. (1968), for Variscan granitoids of Wrocław and Central Sudetes

and in the eastern part of the Strzegom-Sobótka Pluton (Pin and Puziewicz, unpublished data). Slightly less radiogenic isotope ratios characterize the granites $\left(\varepsilon \mathrm{Nd}_{(\mathrm{t})}=-3.8\right.$ to $-5.7)$ and tonalites $\left(\varepsilon \mathrm{Nd}_{(t)}=-4.0\right.$ to -4.3$)$ of the Strzelin Massif (Oberc-Dziedzic et al. 2010a, 2013), and the granitoids of the central and western parts of the StrzegomSobótka Massif (Pin and Puziewicz, unpublished data).

On the $\varepsilon \mathrm{Nd}$ versus $\mathrm{Sm} / \mathrm{Nd}$ diagram (Fig. 8a), the data for the Niemcza Zone, Kłodzko-Złoty Stok and KudowaOlešnice granitoids form three separate clusters. The Kątna granodiorite and one sample of the Niemcza granodiorite fall into the Kłodzko-Złoty Stok granitoids cluster.
The model ages $\mathrm{T}_{\mathrm{DM}}$ in particular groups of the CS granitoids are similar, within the range of $1.11-1.50 \mathrm{Ga}$ (Table 3). However, the two older dates, at 1.41 and $1.50 \mathrm{Ga}$, are most likely biased to spuriously old values because their ${ }^{147} \mathrm{Sm} /{ }^{144} \mathrm{Nd}$ ratios were increased during igneous crystallization by fractionation of LREE-rich phases. Excluding these two samples, a $\mathrm{T}_{\mathrm{DM}}$ model age of $1.2 \pm 0.1 \mathrm{Ga}$ can be inferred for the average source materials of the CS granitoids, similar to those calculated for tonalites of the Strzelin Massif (1.11-1.20) (ObercDziedzic et al. 2010a, 2013). Although this model age is obviously devoid of any direct geological significance, it 
Table $3 \mathrm{Sm}-\mathrm{Nd}$ isotope data for the Variscan granitoids of Wrocław and Central Sudetes

\begin{tabular}{|c|c|c|c|c|c|c|c|c|c|c|}
\hline & Sample & $\mathrm{Sm}$ & $\mathrm{Nd}$ & ${ }^{147} \mathrm{Sm} /{ }^{144} \mathrm{Nd}$ & ${ }^{143} \mathrm{Nd} /{ }^{144} \mathrm{Nd}$ & $\varepsilon \mathrm{Nd}_{0}$ & $\varepsilon \mathrm{Nd}_{(\mathrm{t})}$ & Age (t) Ma & $\mathrm{T}_{\mathrm{CHUR}}$ & $\mathrm{T}_{\mathrm{DM}}(\mathrm{Ga})$ \\
\hline Wrocław granitoids & KAT & 7.29 & 36.7 & 0.1200 & 0.512275 & -7.1 & -3.7 & 350 & & 1.25 \\
\hline \multirow[t]{5}{*}{ Niemcza granitoids } & KOS 426 & 7.47 & 35.2 & 0.1281 & 0.512297 (19) & -6.7 & -3.7 & 340 & 0.76 & 1.33 \\
\hline & NIE 428 & 12.8 & 58.4 & 0.1329 & $0.512396(12)$ & -4.7 & -2.0 & 340 & 0.59 & 1.23 \\
\hline & PRZ 603 & 9.52 & 43.1 & 0.1333 & $0.512415(20)$ & -4.4 & -1.6 & 340 & 0.54 & 1.20 \\
\hline & PRZ 1 & 9.45 & 46.9 & 0.1218 & $0.512376(7)$ & -5.1 & -1.9 & 340 & 0.54 & 1.11 \\
\hline & PRZ 2 & 12.3 & 55.8 & 0.1330 & $0.512359(7)$ & -5.4 & -2.7 & 340 & 0.67 & 1.30 \\
\hline \multirow{8}{*}{$\begin{array}{l}\text { Kłodzko-Złoty Stok } \\
\text { granitoids }\end{array}$} & KLO 2 & 5.60 & 26.1 & 0.1299 & $0.512320(18)$ & -6.2 & -3.3 & 340 & 0.73 & 1.32 \\
\hline & KLO 3 & 5.48 & 29.9 & 0.1109 & $0.512262(7)$ & -7.3 & -3.7 & 340 & 0.67 & 1.16 \\
\hline & KLO 4 & 5.08 & 27.0 & 0.1137 & $0.512282(17)$ & -6.9 & -3.4 & 340 & 0.66 & 1.17 \\
\hline & KLO 5 & 5.33 & 27.4 & 0.1177 & $0.512267(8)$ & -7.2 & -3.9 & 340 & 0.72 & 1.24 \\
\hline & KLO 8a & 4.19 & 17.7 & 0.1430 & $0.512350(16)$ & -5.6 & -3.3 & 340 & 0.83 & 1.50 \\
\hline & KLO 8b & 9.00 & 43.8 & 0.1243 & $0.512301(7)$ & -6.6 & -3.5 & 340 & 0.72 & 1.27 \\
\hline & DRO & 7.31 & 37.6 & 0.1176 & $0.512299(9)$ & -6.6 & -3.2 & 340 & 0.66 & 1.18 \\
\hline & KLO 9 & 1.67 & 7.35 & 0.1376 & $0.512342(10)$ & -5.8 & -3.3 & 340 & 0.77 & 1.41 \\
\hline Olešnice granodiorite & $\mathrm{OL}$ & 5.79 & 32.6 & 0.1075 & $0.512131(4)$ & -9.9 & -6.3 & 320 & 0.73 & 1.31 \\
\hline
\end{tabular}
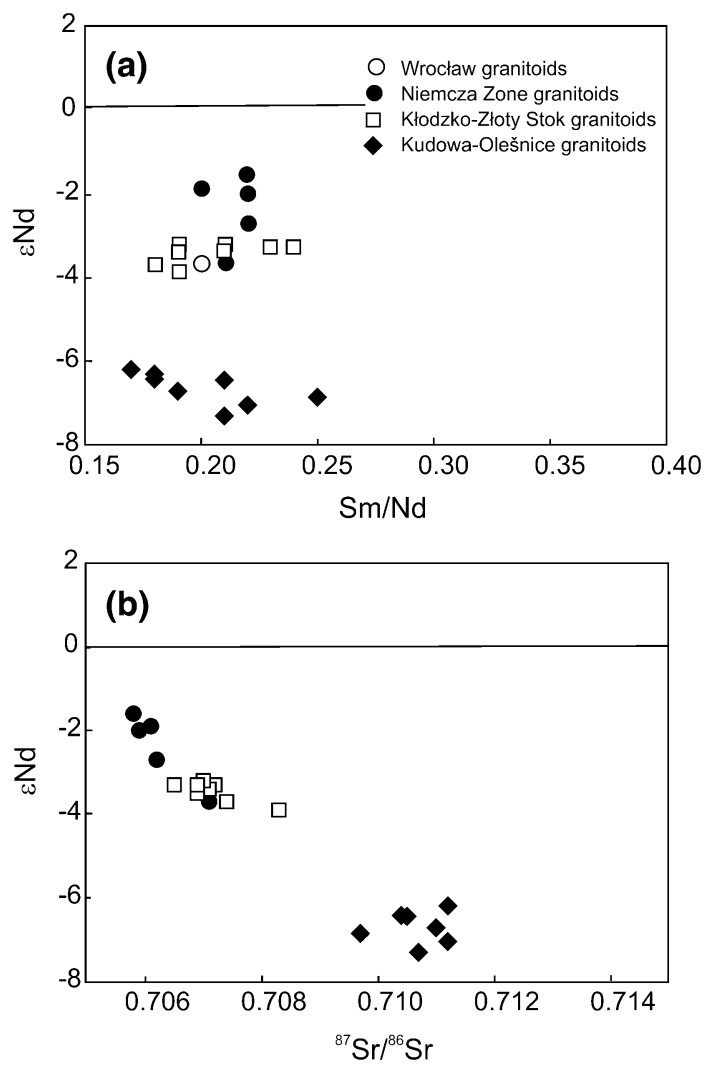

Fig. 8 a The $\varepsilon N d$ vs $\mathrm{Sm} / \mathrm{Nd}$ diagram and $\mathbf{b} \varepsilon \mathrm{Nd}$ versus ${ }^{87} \mathrm{Sr}^{86} / \mathrm{Sr}_{\mathrm{i}}$ for the Variscan granitoids of the Central Sudetes and Middle Odra Fault Zone. Data for the Wrocław, Niemcza and Kłodzko-Złoty Stok granitoids from Tables 3 and 4, for the Kudowa-Olešnice granitoids from Bachliński (2007) is younger than the apparent crustal residence ages of 1.4$1.7 \mathrm{Ga}$ in the Hercynian fold belt of Europe (Liew and Hofmann 1988), thereby reflecting a lesser involvement of old (typically $2 \mathrm{Ga}$ or more) recycled crustal components in the genesis of the CS granitoids.

$\mathrm{Rb}$ and $\mathrm{Sr}$ isotopes

The $\mathrm{Rb}$ and $\mathrm{Sr}$ data for the Niemcza and Kłodzko-Złoty Stok granitoids are given in Table 4 . The ${ }^{87} \mathrm{Sr}^{86} \mathrm{Sr}_{\mathrm{t}}$ values were calculated for the zircon ages obtained by either SHRIMP (Kłodzko-Złoty Stok granitoids, this paper) or multigrain evaporation method (Niemcza granitoids, Oliver et al. 1993). In all samples from these two areas, the ${ }^{87} \mathrm{Sr} /{ }^{86} \mathrm{Sr}_{\mathrm{t}}$ ratios are relatively high, $0.7061-0.7083$. The Niemcza diorites show less radiogenic signatures of $0.7054-0.7059$. Much higher ${ }^{87} \mathrm{Sr} /{ }^{86} \mathrm{Sr}_{\mathrm{t}(331)}$ ratios of 0.7096-0.7111 were found in the Kudowa granitoids (Bachliński 2007).

On the $\varepsilon N d$ versus ${ }^{87} \mathrm{Sr}^{86}{ }^{86} r_{i}$ diagram (Fig. $8 b$ ), the projection points of the Niemcza, Kłodzko-Złoty Stok and Kudowa-Olešnice granitoids form a distinct linear trend. The Niemcza diorites, with the lowest ${ }^{87} \mathrm{Sr}^{86}{ }^{86} r_{i}$ ratio and the highest $\varepsilon \mathrm{Nd}$, are located in the upper part of this trend, the Kośmin granodiorite from the Niemcza Zone together with the Kłodzko-Złoty Stok granitoids, both displaying high ${ }^{87} \mathrm{Sr} /{ }^{86} \mathrm{Sr}_{\mathrm{i}}$ ratio and low $\varepsilon \mathrm{Nd}$, are grouped in the middle of the trend. With their high ${ }^{87} \mathrm{Sr}^{86} \mathrm{Sr}_{\mathrm{i}}$ ratio and low $\varepsilon \mathrm{Nd}_{i}$ values, the Kudowa-Olešnice granitoids are separated by a considerable gap from the other granitoids, highlighting 
Table $4 \mathrm{Rb}-\mathrm{Sr}$ results for the Niemcza and Kłodzko-Złoty Stok granitoids

\begin{tabular}{|c|c|c|c|c|c|}
\hline & $\mathrm{Rb}$ & $\mathrm{Sr}$ & ${ }^{87} \mathrm{Rb} /{ }^{86} \mathrm{Sr}$ & ${ }^{87} \mathrm{Sr} /{ }^{86} \mathrm{Sr}$ & ${ }^{87} \mathrm{Sr} /{ }^{86} \mathrm{Sr}_{(\mathrm{t})}$ \\
\hline \multicolumn{6}{|c|}{ Niemcza granitoids } \\
\hline KZM 410 & 164 & 385 & 1.23 & 0.71269 & 0.7067 \\
\hline KOS 426 & 184 & 442 & 1.21 & 0.71299 & 0.7071 \\
\hline KOS 1 & 171 & 444 & 1.11 & 0.71264 & 0.7073 \\
\hline KOS 2 & 175 & 415 & 1.22 & 0.71309 & 0.7072 \\
\hline PRZ 602 & 62.0 & 760 & 0.236 & 0.70708 & 0.7059 \\
\hline PRZ 603 & 67.4 & 696 & 0.278 & 0.70718 & 0.7058 \\
\hline PRZ 1 & 100 & 673 & 0.430 & 0.70822 & 0.7061 \\
\hline PRZ 2 & 85.0 & 746 & 0.330 & 0.70775 & 0.7062 \\
\hline NIE 428 & 130 & 600 & 0.627 & 0.70893 & 0.7059 \\
\hline NIE 542 & 141 & 578 & 0.706 & 0.70910 & 0.7057 \\
\hline BRO 1 & 141 & 591 & 0.690 & 0.70872 & 0.7054 \\
\hline BRO 2 & 135 & 524 & 0.746 & 0.70945 & 0.7058 \\
\hline \multicolumn{6}{|c|}{ Kłodzko-Złoty Stok } \\
\hline \multicolumn{6}{|l|}{ Granitoids } \\
\hline KLO 2 & 132 & 264 & 1.45 & 0.71421 & 0.7072 \\
\hline KLO 3 & 124 & 331 & 1.08 & 0.71263 & 0.7074 \\
\hline KLO 4 & 90.7 & 350 & 0.750 & 0.71072 & 0.7071 \\
\hline KLO 5 & 128 & 438 & 0.846 & 0.71244 & 0.7083 \\
\hline KLO 7 & 115 & 327 & 1.02 & 0.71222 & 0.7073 \\
\hline KLO 8a & 81.5 & 462 & 0.510 & 0.70898 & 0.7065 \\
\hline KLO 8b & 80.7 & 386 & 0.605 & 0.70987 & 0.7069 \\
\hline DRO & 129 & 491 & 0.760 & 0.71064 & 0.7070 \\
\hline KLO 9 & 113 & 120 & 2.73 & 0.72008 & 0.7069 \\
\hline
\end{tabular}

their fairly different origin. Indeed, the source materials of the Kudowa Pluton were characterized, on a time-integrated basis, by relatively high $\mathrm{Rb} / \mathrm{Sr}$ and $\mathrm{Nd} / \mathrm{Sm}$ ratios, a feature typical of relatively mature, felsic upper crustal materials or sediments derived therefrom.

\section{Geochronology}

Published geochronological data

The Middle Odra Fault Zone granitoids, the Leszno Dolne granodiorite (the Szprotawa granitoids; Fig. 1) and the deformed hornblende monzonite from Przedmoście (the Środa Śląska granitoids) yielded an identical single zircon ID-TIMS age of $344 \pm 1$ Ma (Dörr et al. 2006).

The emplacement age of the Niemcza granitoids (the Koźmice granodiorite) was estimated at $338+2 /-3 \mathrm{Ma}$ (ID-TIMS U-Pb, on mechanically abraded zircon and titanite; Oliver et al. 1993). The earlier, much younger K-Ar biotite ages of 300-277 Ma (Depciuch 1972) were also interpreted as the time of cooling (Lorenc and Kennan 2007) but, more likely, could reflect late-stage disturbances.
The zircons from monzodiorites of the Niemcza Zone were dated by Pietranik et al. (2013) at $342 \pm 2$ Ma for Przedborowa, and $336 \pm 2 \mathrm{Ma}$ for Koźmice (LA-ICP-MS). Within analytical uncertainty, these new data overlap the age published by Oliver et al. (1993) and, taken together, they date the igneous emplacement of the dioritic magmas at c. $340 \pm 5 \mathrm{Ma}$.

The Kłodzko-Złoty Stok granitoids were dated at $c$. 298 Ma using the K-Ar method on biotite (Borucki 1966; Depciuch 1972). Recently, much older ages have been obtained with the SHRIMP U-Pb method (Mikulski et al. 2013), at $340 \pm 3 \mathrm{Ma}$ (quartz monzodiorite), $340 \pm 3 \mathrm{Ma}$ (hornblende monzonite) and $337 \pm 3$ Ma (biotite-hornblende granodiorite). Similar in age are granitoids forming apophyses cutting the sedimentary rocks of the eastern part of the Bardo Unit: $342 \pm 3 \mathrm{Ma}$ and $341 \pm 2 \mathrm{Ma}$ (Mikulski and Williams 2014). Tonalite and spessartite dykes in the pluton gave slightly younger ages of $332 \pm 3 \mathrm{Ma}$ and $333 \pm 3 \mathrm{Ma}$, respectively (Mikulski et al. 2013).

The granitoids of the Kudowa-Olešnice Massif dated with the $\mathrm{K}-\mathrm{Ar}$ method on biotite yielded scattered results: 328-293 Ma (Przewłocki et al. 1962), $307 \mathrm{Ma}$ (Borucki 1966), 360-344 Ma (Domečka and Opletal 1974). The same method applied later to seven granitoid samples gave ages within the range of 275-338 Ma. Five of these seven samples yielded ages higher than $314 \mathrm{Ma}$ (average $329 \mathrm{Ma}$ ). The 7-point whole-rock $\mathrm{Rb}-\mathrm{Sr}$ isochron gave the age of $331 \pm 11 \mathrm{Ma}$, with an initial ratio of ${ }^{87} \mathrm{Sr} /{ }^{86} \mathrm{Sr}=0.7103$ (Bachliński 2007, and references therein).

The U-Pb zircon SHRIMP age from the Bt-Hbl Jawornik granitoid is $351.0 \pm 1.3 \mathrm{Ma}$ (Białek 2014), whereas the ${ }^{40} \mathrm{Ar} /{ }^{39} \mathrm{Ar}$ method on hornblende and biotite in the same rock yielded $351 \pm 4$ and $350 \pm 4 \mathrm{Ma}$, respectively, and on muscovite from a Bt-Ms granite $345 \pm 4$ Ma (Białek and Werner 2004). The age of the emplacement of the Staré Město tonalite (located near the boundary between the Central/East Sudetes and NT, Fig. 1, and not taken into detailed consideration in this study) was reported as $339 \pm 7 \mathrm{Ma}$ (Pb-evaporation method on zircon; Parry et al. 1997).

New SHRIMP zircon age data

Three new samples of granitoids were selected for additional SHRIMP zircon dating. They represent the Wrocław granitoids (sample KAT), the Kłodzko-Złoty Stok Massif (sample DRO) and the Kudowa-Olešnice Massif (sample OL).

The results of the zircon analyses are shown in Online Resources 2, 3 and 4, and in Fig. 10a-c. Conventionally, the ages given in text, if not additionally specified, are ${ }^{207} \mathrm{~Pb} /{ }^{206} \mathrm{~Pb}$ ages for zircons older than $650 \mathrm{Ma}$, and 

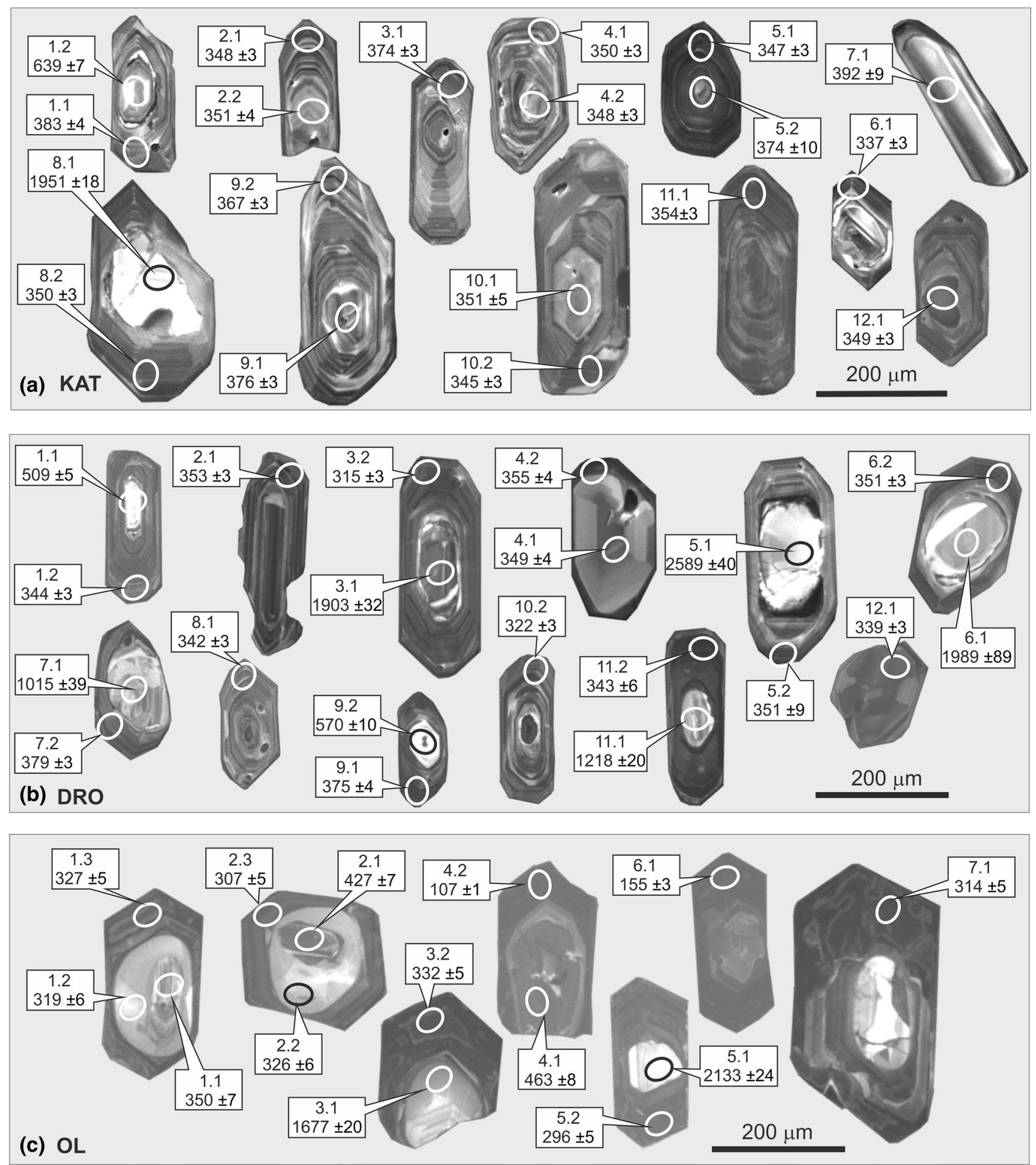

Fig. 9 CL images of selected zircons from the Middle-Odra Fault Zone and Central Sudetes granitoids: a KAT-Kạtna, the Wrocław granitoids; b DRO—Droszków, the Kłodzko-Złoty Stok granitoids; OL—-the Kudowa-Olešnice granitoids. The age data are round

${ }^{206} \mathrm{~Pb} /{ }^{238} \mathrm{U}$ ages for zircons younger than $650 \mathrm{Ma}$. The errors in the text and Online Resources are at $1 \sigma$ level for individual points, and at $2 \sigma$ level in Concordia diagrams and for Concordia ages.

\section{Sample KAT}

Katna 1 borehole $(1769.0 \mathrm{~m})$, the Wrocław granitoids (Fig. 1). 

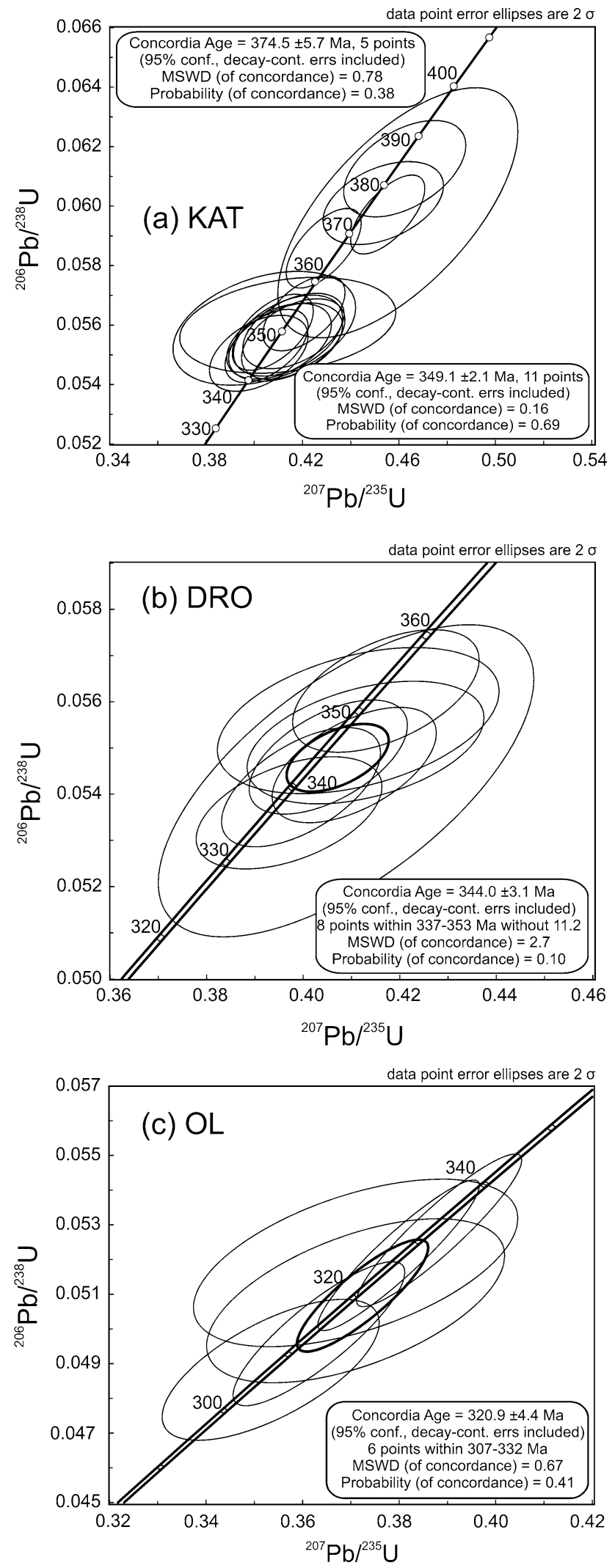

Fig. 10 Concordia diagram for zircons from a sample KAT (the Wrocław granitoids); b sample DRO (the Kłodzko-Złoty Stok granitoids); c sample OL (the Kudowa-Olešnice granitoids)
Petrography The selected granodiorite sample is a coarsegrained, grey-pink rock. The main constituent is subhedral plagioclase, up to $9 \times 3 \mathrm{~mm}$ in size, displaying subparallel alignment. Most grains show indistinct zoning and albite twinning. Most of the plagioclase grains are cracked. Parts of the cracked grains may show weak reorientation. Microcline is less abundant than plagioclase and forms anhedral grains, without perthites, but with rare inclusions of quartz, euhedral plagioclase and biotite. Quartz in anhedral grains shows undulating or mosaic extinction. Dark brown to brown-olive biotite occurs in singular plates or aggregates surrounding plagioclase grains. It often encloses zircon crystals and rare apatite inclusions. Amphibole accompanies biotite or forms separate clusters. The minerals of the granodiorite show evidence of alteration.

Zircon characteristics and ages The zircons are rather homogeneous in their morphology and other physical features. They are mostly normal-prismatic, euhedral to subhedral, with shallow pyramid (101) dominating. They are transparent and clear but contain numerous acicular and oval inclusions. A few crystals are broken. In the CL images, all zircons show strong oscillatory zoning, indicative of magmatic origin. A few grains contain distinct cores, CL bright or of irregular brightness (Fig. 9a).

Twenty spots in 12 grains have been analysed. The ${ }^{206} \mathrm{~Pb}_{\mathrm{c}}$ contents are low, $<0.5 \%$. The $\mathrm{U}$ and $\mathrm{Th}$ concentrations are moderate, $119-1177 \mathrm{ppm} \mathrm{U}$, and 51-485 ppm Th. The ${ }^{232} \mathrm{Th} /{ }^{238} \mathrm{U}$ ratios are fairly constant, around 0.4 .

One spot in the core of a grain (8.1) gives an old ${ }^{207} \mathrm{~Pb} /{ }^{206} \mathrm{~Pb}$ age of $1951 \pm 18(1 \sigma) \mathrm{Ma}$, providing a minimum estimate for the true crystallization age. Another spot located also in the core (1.2) has an almost concordant Neoproterozoic ${ }^{206} \mathrm{~Pb} /{ }^{238} \mathrm{U}$ age of $639 \pm 7 \mathrm{Ma}$ (Online Resource 2).

Five points have ${ }^{206} \mathrm{~Pb} /{ }^{238} \mathrm{U}$ ages scattered between c. 374 and $392 \mathrm{Ma}$, giving an average Concordia age of $374 \pm 6(2 \sigma) \mathrm{Ma}$ (Fig. 10a). However, they all show significant discordance $D$, indicative of partial opening of the U$\mathrm{Pb}$ system; thus, their true ages should be older than their ${ }^{207} \mathrm{~Pb} /{ }^{206} \mathrm{~Pb}$ dates in the $400-470 \mathrm{Ma}$ range.

The main population of 11 points are distributed between $345 \pm 3 \mathrm{Ma}$ and $354 \pm 3 \mathrm{Ma}\left({ }^{206} \mathrm{~Pb} /{ }^{238} \mathrm{U}\right.$ ages, $1 \sigma$ uncertainty), with discordance $D$ scattered around zero (from -13 to $+11 \%$ ). The average Concordia age for this group, calculated as $349 \pm 2(2 \sigma) \mathrm{Ma}$, is interpreted as the likely igneous crystallization age (Fig. 10a).

\section{Sample DRO}

Droszków, the Kłodzko-Złoty Stok granitoids (Fig. 3).

Petrography Sample DRO is a medium-grained, porphyritic rock. Mesoscopically, the rock appears as coarse grained 
because of small size difference between plagioclase phenocrysts $(\sim 7 \mathrm{~mm})$ and clusters of light and dark minerals. All the minerals in the rock are anhedral. Plagioclase shows indistinct normal zoning $\left(\mathrm{An}_{36-48}\right.$, Wierzchołowski 1976) and albite twinning. Plagioclase interiors are often sericitized. Potassium feldspar is not very abundant, up to $5 \mathrm{~mm}$ in size, containing rare inclusions of plagioclase, quartz and biotite. Quartz shows undulatory extinction and wavy boundaries. The grains of light-coloured minerals are surrounded by strips and aggregates of dark minerals: brown biotite, green hornblende and pyroxene (Wierzchołowski 1976). The pyroxene locally forms separate grains but more often is found as relics in hornblende or as inclusions in biotite. Dark minerals are accompanied by accessory apatite and ilmenite. Zircon is found as inclusions in biotite and hornblende.

Zircon characteristics and ages The zircon population looks homogeneous as to the morphology and physical features of grains. The normal-prismatic euhedral crystals are dominated by pyramid (101). They are transparent and clean, and contain rare cores, but rather numerous inclusions. Subtle zonation is common. In the CL images, all the grains display oscillatory, magmatic zonation. Quite many grains contain oval or subhedral, usually CL-brighter cores (Fig. 9b).

Twenty points in 12 grains have been measured. The common lead contents $\left({ }^{206} \mathrm{~Pb}_{\mathrm{c}}\right)$ are low, within the range of $0-0.60$. The $U$ and $T h$ contents may reach 3700 and $1050 \mathrm{ppm}$, respectively, but typically are considerably lower: U c. $150-900 \mathrm{ppm}$, Th c. $65-400 \mathrm{ppm}$. The ${ }^{232} \mathrm{Th} /{ }^{238} \mathrm{U}$ ratios are moderate and fairly constant, usually between 0.3 and 1.0 (Online Resource 3).

The SHRIMP data show strong variation in discordance $\% D$ values, from considerably negative $(-14)$ to strongly positive $(+39)$. In this sample, the ages were calculated with correction of common $\mathrm{Pb}_{\mathrm{c}}$ based on measured ${ }^{208} \mathrm{~Pb}$.

Five spots, mostly located in grain cores, yielded inherited Precambrian ages clearly demonstrating the presence of inherited Precambrian components, with the following ${ }^{207} \mathrm{~Pb} /{ }^{206} \mathrm{~Pb}$ apparent age: $5.1=2602 \pm 13 \mathrm{Ma}$, $6.1=1895 \pm 77 \mathrm{Ma}, 3.1=1940 \pm 9 \mathrm{Ma}$, $11.1=1372 \pm 9 \mathrm{Ma}$ and $7.1=898 \pm 51 \mathrm{Ma}$ (uncertainties quoted at $1 \sigma$ level). Among them, spots 5.1 and 6.1 are almost concordant and can be interpreted to reflect inherited zircon cores with c. $2.6 \mathrm{Ga}$ and 1.9 Ga primary crystallization ages, respectively.

Four other spots gave scattered ${ }^{206} \mathrm{~Pb} /{ }^{238} \mathrm{U}$ dates: $570 \pm 9 \mathrm{Ma}$ (9.2 core), $510 \pm 5 \mathrm{Ma}(1.1), 377 \pm 3 \mathrm{Ma}$ (7.2) and $364 \pm 3 \mathrm{Ma}$ (9.1). The two first may represent Late Proterozoic and Cambro-Ordovician inherited or xenocrystic components, respectively, while the two younger dates are of doubtful significance due to their high degree of discordance (of reverse type for 7.2 and, accordingly, analytically suspect).
The largest group of 8 points show broadly coherent ${ }^{206} \mathrm{~Pb} /{ }^{238} \mathrm{U}$ ages between $337 \pm 3 \mathrm{Ma}$ (point 6.2 ) and $353 \pm 3 \mathrm{Ma}$ (point 2.1), allowing to calculate an average Concordia age (excluding extremely $\mathrm{U}$ - and Th-rich point DRO 11.2) of $344 \pm 3(2 \sigma)$ Ma (Fig. 10b).

Finally, two spots (10.1 and 3.2) give considerably younger ${ }^{206} \mathrm{~Pb} /{ }^{238} \mathrm{U}$ dates of $329 \pm 3$ and $326 \pm 3(1 \sigma)$, respectively, depart from the coherent and older main population. These data are tentatively interpreted to reflect radiogenic lead loss during the postigneous evolution.

\section{Sample OL}

Olešnice (Czech Republic), the Kudowa granitoids (Fig. 5).

Petrography Sample OL is a medium-grained, grey rock showing parallel alignment of minerals. It is composed of tightly packed, rounded, sometimes euhedral plagioclase grains, $2-3 \mathrm{~mm}$ in diameter. The twinning and zoning of plagioclase is poorly expressed. The grains do not show any signs of deformation and only faint alteration documented by sericite. The plagioclase grains are wrapped with strips of olive-brown biotite with zircon inclusions. Biotite is accompanied by altered amphibole and accessory apatite. The space between plagioclase grains is filled with very fine aggregate of plagioclase and quartz, penetrated by amoeboid grains of microcline and myrmekite. Rarely, between plagioclase grains, mosaic quartz aggregates appear. The rounded shape of plagioclase, together with the lack of brittle deformation, as well as the presence of the very fine-grained multi-mineral and quartz mosaic aggregates, points to high-temperature, submagmatic deformation (Passchier and Trouw 2005).

Zircon characteristics and ages The zircon population in this sample is very uniform: euhedral crystals are moderately clean, short to normal prismatic, with one shallow (101) prism dominating. A few crystals are broken (during separation?). In the CL images, the zircon crystals display a very characteristic structure: they often contain a distinct, usually oval (resorbed) core and thinner or broader overgrowths. The cores are very bright and the rims are very dark, corresponding to contrasting $\mathrm{U}$ and Th contents (high in the rims) (Fig. 9c).

Two spots, out of the total of 14 in seven grains measured, have very high ${ }^{206} \mathrm{~Pb}_{\mathrm{c}}$, above $6 \%$. Interestingly, one of them (1.1) is $U$ low, while the other (6.1) is extremely rich in U. The corresponding dates are problematic and should be treated with caution.

A striking feature of the zircons in this sample is their bimodal distribution, as far as the $\mathrm{U}$ and Th concentrations are concerned. In general, the rounded cores are $\mathrm{U}$ and $\mathrm{Th}$ poorer (c. 100-500 ppm U, and c. 15-130 ppm Th) and, consequently, $\mathrm{CL}$ bright, whereas the rims are $\mathrm{U}$ and $\mathrm{Th}$ 
rich (up to $13,097 \mathrm{ppm} \mathrm{U}$, and $1353 \mathrm{Th}$ ). The ${ }^{232} \mathrm{Th} /{ }^{238} \mathrm{U}$ ratios vary from 0.06 to 0.54 , irrespectively of the $U$ and $T h$ concentrations (Online Resource 4).

Two spots clearly represent inherited Precambrian materials: $5.1=2133 \pm 24(D+2)$ and $3.1=1677 \pm 20 \mathrm{Ma}(D$ $+9 \%)$. Three other spots are also older compared with the main age groups, with ${ }^{206} \mathrm{~Pb} /{ }^{238} \mathrm{U}$ ages: $4.1=463 \pm 8 \mathrm{Ma}$, $1.1=350 \pm 7 \mathrm{Ma}$ (with a high common $\mathrm{Pb}=6.7 \%$ ) and $2.1=427 \pm 7 \mathrm{Ma}$. Taking into account the relatively highpositive discordance $D$ (particularly in the first two points), their ages can be considered as minimum ages only.

The ages of the main group are scattered between $\mathrm{c}$. 307 and $332 \mathrm{Ma}$, with the mean Concordia age for six points $=321 \pm 4(2 \sigma) \mathrm{Ma}$ (Fig. 10c). However, the interpretation of the data is not straightforward. This age may average two magmatic episodes: crystallization of magma I (probably at around 325-332 Ma) that produced the cores, followed by injection of U- and Th-rich magma II events (at around $307 \mathrm{Ma}$ ) that caused partial resorption of older zircons and crystallization of U- and Th-rich overgrowths. Alternatively, and more likely, this could reflect magma mixing in the scope of a single episode (at about $330 \mathrm{Ma}$ ?) and, subsequently, the $\mathrm{U}$ - and Th-rich zircon rims might have suffered some radiogenic lead loss, as it is obvious for spots 4.2 and 6.1 with spurious ${ }^{206} \mathrm{~Pb} /{ }^{238} \mathrm{U}$ ages as young as 108 and $155 \mathrm{Ma}$.

\section{Discussion}

Geological boundaries in the Central Sudetes and distribution of granitoids

The concentration of the Variscan intrusive rocks in major shear zones in the Central Sudetes and in the Middle Odra Fault Zone is indicative of a very close link between tectonic and magmatic processes at that stage of the Variscan orogeny.

The Niemcza and the Kudowa-Olešnice granitoids are evidently spatially related to shear zones (the Niemcza Shear Zone and the Nové Město-Orlica-Śnieżnik Shear Zone, respectively) which are considered as the boundary between the Teplá-Barrandian and Moldanubian terranes in the NE part of the Bohemian Massif (Mazur et al. 2006).

Another part of this terrane boundary could have been a hypothetical pre-intrusive, sinistral strike-slip fault, $\mathrm{N}-\mathrm{S}$ oriented and parallel to the eastern margin of the Bardo Structural Unit (Fig. 3; Oberc 1995). This pre-intrusive fault separated the Teplá-Barrandian Terrane hidden under the Bardo Unit (the Góry Sowie gneisses, Chorowska et al. 1987, and the Kłodzko Metamorphic Unit, Oberc 1987) to the west, from the Moldanubian Terrane, represented by the roof pendants of the Kłodzko-Złoty Stok Massif to the east. This pre-intrusive fault could have been the southern prolongation of the sinistral Niemcza Shear Zone (Oberc 1995) and used as a magma feeding channel of the Kłodzko-Złoty Stok Massif. At present, the fault is masked by the granitoids (Oberc 1995).

The Skrzynka Shear Zone, regarded by some authors (e.g. Dumicz 1988; Cymerman 1996; Mazur et al. 2006) as the southern prolongation of the Niemcza Shear Zone, cut only the Moldanubian rocks represented by roof pendants of the Kłodzko-Złoty Stok Massif on the west and by the rocks of the Orlica-Śnieżnik Dome on the east. Thus, it does not seem to separate two major tectonostratigraphic units (terranes). The Skrzynka Zone, intruded by the relatively older Jawornik granitoids (cf. c. $350 \mathrm{Ma} \mathrm{U}-\mathrm{Pb}$ and $\mathrm{Ar}-\mathrm{Ar}$ cooling ages) was probably tectono-thermally active earlier than the hypothetical fault used by the KłodzkoZłoty Stok granitoids.

Emplacement and origin of internal structures of intrusions in the Central Sudetes

The granitoids of the Niemcza, Jawornik and of the southern part of the Kudowa-Olešnice intrusions form sheetlike bodies. The borders of these intrusions are parallel to the foliation in the surrounding metamorphic rocks (Burchart 1960; Dziedzicowa 1963; Białek and Werner 2002). The parallelism of the flattened enclaves and the foliation in the Niemcza granitoids and the parallelism of long axes of enclaves and the lineation in these rocks (Dziedzicowa 1963) suggest that the emplacement and the early stage of crystallization of the Niemcza granitoids were syntectonic, i.e. overlapped with the deformation in the country rocks. This view is supported by the presence of the subhorizontal magnetic lineation recorded not only in mylonites and gneisses, but also in the majority of the intrusive bodies, even those which look as non-deformed (Werner 2002).

The Kłodzko-Złoty Stok Pluton shows a domal structure which is documented by the orientation of the magmatic foliation (Fig. 3; Wojciechowska 1975). The three domal structures recognized in this pluton were fed with magma delivered by NW-SE-oriented channels (Wojciechowska 1975) or, alternatively, along the NNE-SSW-trending, hypothetical fault (Oberc 1987, 1995). It is possible that the NW-SE channels were subordinate to the main NNESSW-striking magma feeder system (Oberc 1987, 1995). It is also likely that the Kłodzko-Złoty Stok and the Niemcza granitoids originally formed a single plutonic system. Because of deeper erosion level in the Fore-Sudetic Block, compared with that in the Sudetes, the northern part of this hypothetical pluton (the Niemcza granitoids) would represent at least a c. $2.5 \mathrm{~km}$ deeper level (a feeder zone of the pluton) than its southern part (the Kłodzko-Złoty Stok Massif, corresponding to a zone of magma accumulation). 
The formation of the Kudowa-Olešnice Massif started with the emplacement of the microtonalite dykes which were folded during the main $\mathrm{F}_{2}$ deformational phase (Żelaźniewicz 1977). At the next stage, the older granitoid intruded as sills into the Stronie Ślaskie schists in the western part of the Orlica-Śnieżnik Dome. Some of these sills were folded during the $\mathrm{F}_{4}$ phase. The younger, more acidic granitoid that forms the northern, larger part of the pluton is postkinematic (Żelaźniewicz 1977). It forms a dome structure defined by the protoclastic foliation (Żelaźniewicz 1977). It is further inferred that the magma of the northern part of the pluton was delivered through a channel located in the western part of the massif.

The estimated pressures suggest that the granitoids forming thin and long dykes inside the shear zones (the Niemcza and Jawornik granitoids) were emplaced at midcrustal level. In contrast, the larger plutons were emplaced at a shallower crustal level. The Kłodzko-Złoty Stok pluton showing dome-like form, which intruded the sedimentary rocks of the Bardo Unit (Wierzchołowski 1976; Wojciechowska 1975) was emplaced at an uppermost crustal level. The northern part of the Kudowa pluton, showing a loaf form, intruded medium-grade metamorphosed schists of the Stromie Slaskie Formation. However, the protoclasis structures (Żelaźniewicz 1977) in the granitoids, characteristic for shallowly emplaced rocks (Sylvester et al. 1978; Alekseev 2010), suggest that the schists were part of the upper crust during the emplacement of the Kudowa granitoids.

\section{Origin of magmas}

The CS granitoids correspond mostly to metaluminous rocks of intermediate composition, characterized by a relatively high $\mathrm{K}_{2} \mathrm{O}$ content (Table 2). Peraluminous granites are less abundant. The presence of hornblende, clinopyroxene and mafic enclaves in the granitoids clearly points to the admixtures of mafic components.

The trace-element characteristics of the CS and MOFZ granitoids show various chemical anomalies, e.g. usually distinct negative $\mathrm{Nb}$ and $\mathrm{Ti}$ anomaly. Some of these anomalies are observed only in some of the granitoids, suggesting that different source materials and resulting partial melts were involved in the generation of the magmas. For example, the OL sample of the Kudowa Massif displays a HREE depletion which might reflect a magma extracted from a relatively deep crustal source containing residual garnet; the crustal origin of this granite is confirmed by its $\mathrm{Sr}-\mathrm{Nd}$ radiogenic isotopes. All the $\mathrm{CS}$ and Wrocław granodiorites display similar $\mathrm{Eu} / \mathrm{Eu}^{*}$ anomalies, but different from those reported form other granitoids in the Sudetes (e.g. in the Karkonosze and Strzelin massifs). These differences might reflect either different source reservoirs or variable extent of plagioclase fractionation and diverse oxidation states of the magmas.

Pietranik et al. (2013) report that the diorites from the Niemcza Shear Zone record a change in geochemistry from high K (the Przedborowa type) to shoshonitic (the Koźmice type and Kośmin enclaves) and, locally, also ultrapotassic magmas (Wilków Wielki) (Fig. 2). The older diorites (the Przedborowa type) are lower in $\mathrm{K}_{2} \mathrm{O}, \mathrm{MgO}, \mathrm{Rb}$ and $\mathrm{Ni}$ than the younger ones (the Koźmice type). According to Pietranik et al. (2013), if the age difference between Przedborowa (342 $\pm 2 \mathrm{Ma}$ ) and Koźmice (336 $\pm 2 \mathrm{Ma})$ diorites is real, it correlates with a change in magma chemistry, from high $\mathrm{K}$ to shoshonitic, over approximately $5 \mathrm{Ma}$. A similar compositional trend was also observed in the Central Bohemian Plutonic Complex (Pietranik et al. 2013).

The ${ }^{87} \mathrm{Sr} /{ }^{86} \mathrm{Sr}_{\mathrm{t}}$ ratios span a relatively large range (0.7054-0.7073) in the Niemcza granitoids (Table 4), as do the $\varepsilon \mathrm{Nd}_{i}$ values (from -6 to -3.7 , Table 3 ), suggesting that the contribution of the mafic materials characterized by relatively primitive $\mathrm{Sr}-\mathrm{Nd}$ isotope signatures varied from considerable in diorites to lower in granodiorites. The strong LREE enrichment and high concentrations of $\mathrm{Ba}$ and $\mathrm{Sr}$ further suggest that this component was extracted from an enriched-mantle source. According to Lorenc (1998) and Lorenc and Kennan (2007), the field evidence from the Niemcza Zone and the different initial ${ }^{87} \mathrm{Sr} /{ }^{86} \mathrm{Sr}$ ratios of individual rock types indicate that the particular magmas did not interact. Moreover, isotopic data suggest that the rocks of the Niemcza Shear Zone did clearly not derive from a single homogeneous source. Processes of igneous mixing and/or contamination may have operated at the source, containing both mantle and crustal components, but it is also probable that this source was previously mixed. Individual magmas may have been simultaneously intruded from separate magma chambers or from different levels of one extensive magma chamber (Lorenc and Kennan 2007).

In the Kłodzko-Złoty Stok granitoids, the ${ }^{87} \mathrm{Sr} /{ }^{86} \mathrm{Sr}_{\mathrm{t}}$ ratios range from 0.7065 to 0.7083 (Table 4 ), while $\varepsilon \mathrm{Nd}_{i}$ values show little scatter (from -3.2 to -3.9 ) suggesting open-system petrogenetic processes starting from a relatively primitive end-member similar to the most evolved magmas found in the Niemcza Zone (e.g. KOS 426) that interacted with crustal components having more radiogenic $\mathrm{Sr}$ isotopes. However, an interpretation in terms of simple combined assimilation-fractional crystallization (AFC) is not favoured, because the sample with the most radiogenic ${ }^{87} \mathrm{Sr}^{86} \mathrm{Sr}_{\mathrm{t}}$ (KLO 5, 0.7083) and unradiogenic $\mathrm{Nd}\left(\varepsilon \mathrm{Nd}_{i}=-3.9\right)$ does not correspond to a chemically evolved magma, based on its relatively low ${ }^{87} \mathrm{Rb} /{ }^{86} \mathrm{Sr}$ ratio $(0.85)$ and major element features. Conversely, the pegmatite KLO 9, representative of the most fractionated melt, does not display more crustal isotope signatures $\left({ }^{87} \mathrm{Sr} /{ }^{86} \mathrm{Sr}_{\mathrm{t}}=0.7069 ; \varepsilon \mathrm{Nd}_{i}=-3.3\right)$ than the rest of the samples. More complex interactions 
were probably involved. However, when compared to the large range found in the Niemcza Zone granitoids, the relatively homogeneous isotopic signature is consistent with the interpretation of the Kłodzko-Złoty Stock body as a zone of magma storage and homogenization.

Much higher Sr isotope ratios (0.7096-0.7112), characteristic for crustal magmas, are found in the KudowaOlešnice granitoids (Bachliński 2007), suggesting metasedimentary rocks, along with possible felsic igneous rocks, as a suitable source material for their parent magmas (Bachliński 2007). The initial ratios of ${ }^{87} \mathrm{Sr}^{86} \mathrm{Sr}_{331}$ in the Kudowa-Olešnice Massif are higher than in the other granitoids in the Sudetes, e.g. in the Karkonosze granite 0.7043-0.7090 (Kryza et al. 2014) and in the fine-grained biotite Strzelin granite- 0.7070 , but comparable with the highly radiogenic values $(0.716-0.722)$ measured in the biotite-muscovite Strzelin granites (Oberc-Dziedzic et al. 2013, recalculated from Oberc-Dziedzic et al. 1996).

In short, the following overall picture is arising from the Sm-Nd isotope characteristics of the CS granitoids: (1) strongly unradiogenic in the Kudowa-Olešnice granites, which can be interpreted as almost purely crustal partial melts; (2) mildly unradiogenic in the Kạtna, Kłodzko-Złoty Stok and Niemcza granodiorites, which most likely reflect hybridization processes between mafic end-members and crustal melts, and (3) very weakly unradiogenic in the Niemcza diorites, which provide the closest candidate for the mantle-derived end-member. Moreover, the $\mathrm{Nd}$ isotope data reflect average source materials that were not strongly enriched in LREE on a time-integrated basis and, therefore, rule out - with the exception of the Kudowa Pluton-a largely dominant role for ancient continental crust or sediments derived from such old crustal sources, characterized by strongly negative $\varepsilon \mathrm{Nd}_{(t)}$ values.

The strong LREE enrichment observed in the isotopically rather primitive Niemcza granitoids, combined with elevated $\mathrm{Ba}$ and $\mathrm{Sr}$ contents, is remiscent of an enrichedmantle source, although the weakly negative $\varepsilon \mathrm{Nd}$ values implies that this enrichment was not a very old feature.

Although the CS granitoids show differences in their ${ }^{87} \mathrm{Sr}^{86} \mathrm{Sr}_{\mathrm{i}}$ and $\varepsilon \mathrm{Nd}_{t}$ values, which are observed not only between particular massifs but also inside particular intrusions, they are very similar in their incompatible trace-element characteristics. The observed low $\mathrm{Th} / \mathrm{Nb}(0.59-1.9)$ and high $\mathrm{La} / \mathrm{Nb}(1.6-4.6)$ ratios reflect depletion of $\mathrm{Nb}$ relative to other incompatible elements and might indicate a crustal origin of the granitoids (Hofmann 1988; McLennan et al. 2006; Oberc-Dziedzic et al. 2009a). However, several features are at odd with this interpretation, including the overall mafic major element composition and the very high contents in $\mathrm{Sr}$ and $\mathrm{Ba}$, which cannot be accounted for by crustal sources, but instead require a substantial contribution of mafic magmas, that were extracted from enriched-mantle reservoirs.
By essence, there is little isotopic contrast between such enriched-mantle domains and crustal end-members, and their incompatible trace elements show great resemblances.

The old zircon inheritance was not the primary target of our new SHRIMP study; thus, the data on the old zircons are rather limited. The oldest, late Archean zircon, c. $2.60 \mathrm{Ga}$ in age, was found in the Kłodzko-Złoty Stok granodiorite (sample DRO) where the spectrum of measured inheritance comprised also two Palaeoproterozoic grains (c. $1.90 \mathrm{Ga}$ ) and two younger ones of 1.37 and $0.90 \mathrm{Ga}$. In the Kudowa granite (sample OL), two grains show 2.13 and $1.68 \mathrm{Ga}$, and another one yielded an imprecise age of c. $565 \pm 71 \mathrm{Ma}$. In the Wrocław granitoid of Kątna (KAT), one older zircon was measured at c. $1.95 \mathrm{Ga}$ and another Precambrian grain gave an imprecise date of $606 \pm 60 \mathrm{Ma}$.

Whether these Precambrian zircons were inherited from the major magma source(s) and/or correspond to xenocrysts picked from crustal country rocks during magma ascent and emplacement cannot be ascertained, but the presence of such a diverse inherited zircon population most likely reflects the significant contribution of metasedimentary components in the crustal end-member(s) which contributed to the petrogenesis of some of the CS granitoids.

The inherited zircons in the Variscan granitoids of the CS and MOFZ show similar age spectra as those in the Late Cadomian and Early Ordovician granitoids in the West and East Sudetes (Turniak et al. 2000; ObercDziedzic et al. 2003, 2009a, b, 2010b; Żelaźniewicz et al. 2009b). In a wider regional context, the scarce inheritance measured in the granitoids of the study area is typical of the crustal rocks of the Central European Variscides (e.g. Zeh et al. 2001), but the limited data available do not allow for detailed large-scale palaeotectonic interpretations.

\section{Thermal history of the Central Sudetes shear zones}

In all of the Central Sudetes shear zones discussed in this paper (the Niemcza, Skrzynka and Nové Město-OrlicaŚnieżnik shear zones), and probably also in the Middle Odra Fault Zone, the emplacement of granitoids was preceded by an increase in the thermal gradient, as indicated by the crystallization of andalusite, cordierite and sillimanite in the regionally metamorphosed country rocks (Kozłowska-Koch 1973; Oberc and Oberc-Dziedzic 1978; Dziedzicowa 1963, 1987; Mazur and Józefiak 1999; Mazur et al. 2005). In the Niemcza Shear Zone, the mylonitization took place at relatively high temperatures allowing for the crystallization of syndeformational sillimanite and biotite (Mazur and Puziewicz 1995).

The rocks of the shear zones in the study area were subsequently thermally metamorphosed at the contacts with granitoid bodies (Kozłowska-Koch 1973; Dziedzicowa 1987). The contact aureoles of the Niemcza, 


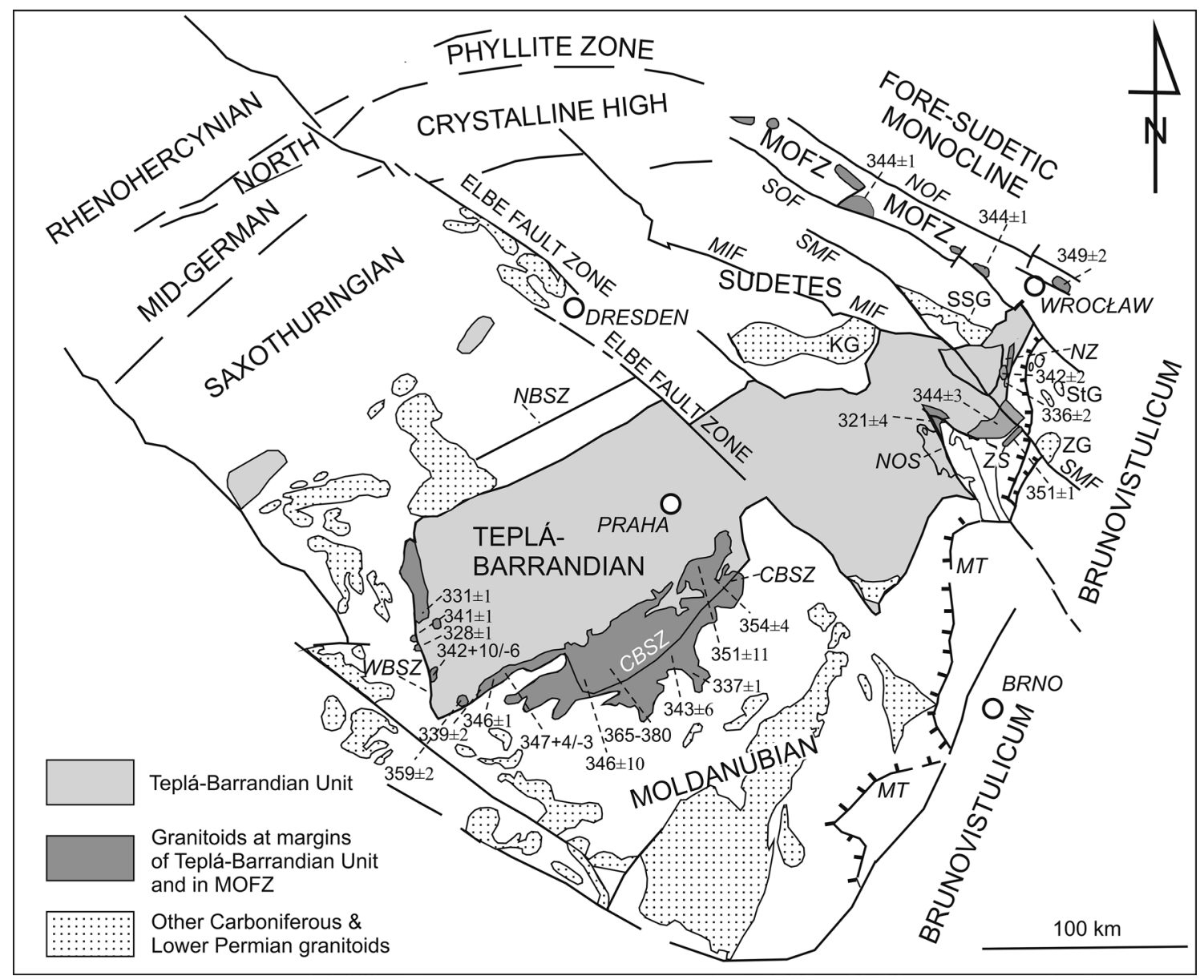

Fig. 11 Geological sketch of the Bohemian Massif compiled from Dörr and Zulauf (2010), Franke (2012), Klomínský et al. (2010) and Fig. 1, showing the position and age of granitoid plutons along main faults and shear zones bordering the Tepla-Barandian Unit. CBSZCentral Bohemian Shear Zone, NBSZ-North Bohemian Shear Zone, WBSZ-West Bohemian Shear Zone, NZ-Niemcza Shear Zone, ZS-Złoty Stok-Skrzynka Shear Zone, NOS—Nové Město-Orlica-

Kudowa-Olešnice and Jawornik granitoids, situated inside the shear zones, were narrow, because of the small size of these intrusions, and metamorphic alterations were limited mainly to the static recrystallization. Only the thermal aureole of the Kłodzko-Złoty Stok Massif was wider, estimated at, at least, several hundred metres (Bagiński 2002), covering also the western part of the Skrzynka Shear Zone.

The granitoids of the Central Sudetes and Middle Odra Fault Zone compared with plutons related to the major Central Bohemian Shear Zone

The Central Sudetes granitoids are spatially and temporally related to shear zones. The ages of the CS and MOFZ granitoids are bracketed between $351 \mathrm{Ma}$ (the Jawornik intrusion) and 332 (307) Ma (the Kudowa-Olešnice Massif)
Śnieżnik Shear Zone, MOFZ-Middle Odra Fault Zone; granitoids: SSG-Strzegom-Sobótka, KG-Karkonosze, StG-Strzelin, ZGŽulova; faults: NOF-Northern Odra Fault, SOF-Southern Odra Fault, SMF-Sudetic Marginal Fault, MIF-Main Intra-Sudetic Fault; MT-Moldanubian Thrust. For the sake of clarity, the size of the Niemcza, Kłodzko-Złoty Stok, Kudowa-Olešnice and Jawornik intrusions (Figs. 1, 2, 3, 4) is enlarged 2 times

(Table 1). These data suggest that the shear zone-related plutonism was a protracted process, lasting at least $\mathrm{c}$. $20 \mathrm{Ma}$.

Similar ages have been reported from granitoid plutons emplaced along the Central Bohemian Shear Zone and the Western Bohemian Shear Zone, which separate the TepláBarrandian Unit from the Moldanubian Unit (Fig. 11; Dörr and Zulauf 2010).

The eastern part of the Central Bohemian Shear Zone is dominated by the large Central Bohemian Pluton, consisting of several individual intrusions differing in age and composition, and reflecting a magmatic sequence from older calc-alkaline to younger ultrapotassic melts: the Požáry trondhjemite $(351 \pm 11 \mathrm{Ma})$, the Sázava calc-alkaline tonalite/granodiorite with quartz dioritic to gabbroid rocks (354 $\pm 4 \mathrm{Ma}$ ), the Blatna calc-alkaline 
granodiorite (346 $\pm 10 \mathrm{Ma})$, the Čertovo Břemeno durbachites ( $343 \pm 6 \mathrm{Ma})$ and the Tabor Pluton quartz syenites, to melagranites (337 $\pm 1.0 \mathrm{Ma}$ ) (Dörr and Zulauf 2010 and references therein; Fig. 11).

The western part of the Central Bohemian Shear Zone was intruded by the Klatovy Pluton composed of the Klatovy granodiorite $(347+4 /-3 \mathrm{Ma})$, the Kozlovice granodiorite (346 $\pm 6 \mathrm{Ma})$, the Okrajovy granite and the Nyrsko granite (339 $\pm 2 \mathrm{Ma}$ ) (Dörr and Zulauf 2010).

Relatively younger plutons are also present along the Western Bohemian Shear Zone: the Bor granite $(331 \pm 1 \mathrm{Ma})$ on the north, the Muternin gabbro/diorite $(341 \pm 1 \mathrm{Ma})$ and the Drahotin gabbronorite $(328 \pm 1 \mathrm{Ma})$ in the middle part and the Babylon granite $(342+10 /-6 \mathrm{Ma})$ on the south (Dörr and Zulauf 2010) (Fig. 11).

Although the igneous activity related to the Central and Western Bohemian shear zones has a similar age and similar time span of c. $20 \mathrm{Ma}$ (Dörr and Zulauf 2010), as those in the CS and MOFZ (Fig. 11), the igneous rocks in both areas differ considerably. Generally, the granitoids of the CS and MOFZ are represented by acidic rocks: granodiorites and less common tonalites and granites; these magmas originated from crustal sources, with a substantial contribution of mafic magmas that were extracted from enrichedmantle reservoirs as indicated by the trace-element characteristics, $\varepsilon \mathrm{Nd}$ values and radiogenic $\mathrm{Sr}$ isotope signatures. A contribution of mafic magmas is suggested also by mafic enclaves and small bodies of ultrapotassic rocks, e.g. in the Niemcza Shear Zone (Pietranik et al. 2013) and in the Kłodzko-Złoty Stok Massif (Wierzchołowski 1977, 2003). In contrast, plutons related to the Central and Western Bohemian Shear Zones comprise, apart from granodiorite, tonalite and granite, also more mafic, mantle-derived rocks: gabbro, gabbro/diorite, gabro/norite and trondhjemite. The described compositional differences between the magmatic rocks in both areas suggest that mantle contributions were more significant in the Central and Western Bohemian shear zones than in the shear zones of the CS and MOFZ.

\section{Conclusions}

1. The Central Sudetes granitoid plutons are both temporally and spatially related to steep, crustal-scale shear zones, which provided effective channels for melt transport, and plausibly favoured their generation at depth through the ingress of mafic magmas.

2. The steeply inclined, narrow and rather small granitoid intrusions (the Niemcza, Jawornik and the southern part of the Kudowa-Olešnice massifs) were emplaced within shear zones at mid-crustal level (c. $20 \mathrm{~km}$ depth), whereas the larger, flat-lying plutons (the
Kłodzko-Złoty Stok Massif, the northern part of the Kudowa-Olešnice Massif) were emplaced in the upper crust, and outside or above these shear zones.

3. The Central Sudetes granitoids were mainly generated by partial melting of crustal sources, with variable contributions (or no contribution in the Kudowa Pluton) of mafic magmas. The mafic magmas were most likely extracted from enriched-mantle sources showing little contrast with crustal end-members in terms of incompatible trace-element features and $\mathrm{Sr}-\mathrm{Nd}$ isotope signature.

4. The magmatic foliation and lineation in granitoid sheet-like intrusions are concordant with those in the surrounding rocks in the shear zones. This parallelism suggests that the solidification of granitoids was coeval with deformation in the shear zones. Instead, the magmatic foliation in the dome-like plutons is interpreted to reflect magma flow.

5. Ductile, transcurrent movements along the shear zones of the Central Sudetes, and probably also in the Middle Odra Fault Zone, postdate medium-pressure regional metamorphism and were accompanied by an increase in the local thermal gradient, as documented by the crystallization of cordierite, andalusite and sillimanite; this event preceded the emplacement of granitoids and concomitant thermal influence of the magmas.

6. When compared to the intrusions delineating the boundary between the Tepla-Barandian and Moldanubian units in the Central Sudetes, the plutonic rocks related to the Central and Western Bohemian shear zones comprise, apart from evolved acidic lithologies, also more abundant mafic rocks. This suggests a greater contribution of mafic materials of mantle affinity and, possibly, a deeper crustal setting for the Bohemian Shear Zone, compared to a more shallow (upper crustal) level of the shear zones in the Central Sudetes area.

Acknowledgments We thank: Irena Wojciechowska for help in collecting of samples from the Kłodzko-Złoty Stok Massif and for discussion; Jacek Puziewicz for powder samples from the Niemcza Zone granitoids; Kalina Dymna for zircon separation and Pierre Gaudon for generous access to the XRF spectrometer of Ecole Nationale des Mines d'Alès. The early stages of this research were carried under bilateral cooperation between the Université Blaise Pascal, ClermontFerrand and the University of Wrocław. The later investigations were performed within the Project N307 008 32/0314 of the Polish Ministry of Science and Education. Additional support came from internal grants 1017/S/ING and 2022/W/ING of the University of Wrocław. Aleksandra Gawęda and Andrzej Żelaźniewicz are thanked for their constructive reviews.

Open Access This article is distributed under the terms of the Creative Commons Attribution License which permits any use, distribution, and reproduction in any medium, provided the original author(s) and the source are credited. 


\section{References}

Alekseev VI (2010) Mineralogical attributes and causes of high pressure crystallization of Li-F granites. Geol Ore Depos $52: 534-542$

Archanjo CJ, Hollanda MHBM, Rodrigues SWO, Neves BBB, Armstrong R (2008) Fabrics of pre- and syntectonic granite plutons and chronology of shear zones in the Eastern Borborema Province, NE Brazil. J Struct Geol 30:310-326

Awdankiewicz M (2007) Late Palaeozoic lamprophyres and associated mafic subvolcanic rocks of the Sudetes (SW Poland): petrology, geochemistry and petrogenesis. Geol Sudet 39:11-97

Bachliński R (2007) Kudowa-Olešnice granitoid massif. In: Kozłowski A, Wiszniewska J (eds) Granitoids in Poland. AM Monograph No. 1:275-286

Bachliński R, Bagiński B (2007) Kłodzko-Złoty Stok granitoid massif. In: Kozłowski A, Wiszniewska J (eds) Granitoids in Poland. AM Monograph No. 1:261-273

Bagiński B (2002) Contact metamorphism induced by the KłodzkoZłoty Stok intrusion (Sudetes, Poland). Mineral Soc Pol Spec Pap 20:57-59

Bederke E (1922) Die Intrusivmasse von Glatz-Reichenstein. Tektonik und Magma. Untersuchungen zur Geologie der Tiefen. Abh Preuß Geol LA NF 89:39-70

Bederke E (1929) Die Grenze von Ost- und Westsudeten und ihre Bedeutung für die Einordnung der Sudeten in den Gebirgsbau Mitteleuropas. Geol Rundsch 20:186-205

Białek D (2003) Petrography and geochemistry of the Jawornickie Granitoids, West Sudetes. Mineral Soc Pol Spec Pap 22:22-24

Białek D (2006) Petrography of the Kudowa-Olešnice granitoids (SW Poland) and P-T conditions of its emplacement-preliminary report. Mineral Pol Spec Pap 29:99-102

Białek D (2014) SHRIMP U-Pb zircon geochronology of the Jawornik granitoids (West Sudetes, Poland). Geol Sudet 42:4

Białek D, Werner T (2002) The Jawornickie Grnitoids magnetic fabric and relationship with the Złoty Stok-Skrzynka shear zone. Mineral Soc Pol Spec Pap 20:68-70

Białek D, Werner T (2004) Geochemistry and geochronology of the Javornik Granodiorite and its geodynamic significance in the Eastern Variscan belt. Geolines 17:22-23

Black LP, Kamo SL, Allen CM, Aleinikoff JN, Davis DW, Korsch RJ, Foudoulis C (2003) TEMORA 1: a new zircon standard for Phanerozoic U-Pb geochronology. Chem Geol 200:155-170

Borkowska M (1959) On the granitoids of Kudowa as compared with the main types of the acid intrusions of the Sudeten Mts. and the sudetic foreland (in Polish, English summary). Arch Miner 21:229-382

Borucki J (1966) Preliminary results of K-Ar dating of the Lower Silesia granitoids (in Polish, English summary). Kwart Geol 10:1-18

Burchart J (1960) On the Jawornik Granitoids (Eastern Sudeten) (in Polish, English summary). Arch Miner 22:237-348

Chopin F, Schulmann K, Skrzypek E, Lehmann J, Dujardin JR, Martelat JE, Lexa O, Corsini M, Edel JB, Štípská P, Pitra P (2012) Crustal influx, indentation, ductile thinning and gravity redistribution in a continental wedge: Building a Moldanubian mantled gneiss dome with underthrust Saxothuringian material (European Variscan belt). Tectonics 31:TC1013. doi:10.1029/201 1TC002951

Chorowska M, Milewicz J, Radlicz K (1987) Borehole Zdanów IG-1 (in Polish). Przewodnik 58 Zjazdu PTG. Wałbrzych 17-19 września 1987. ZG AGH Kraków 198-200

Cymerman Z (1996) The Złoty Stok-Trzebieszowice regional shear zone: the boundary of terranes in the G6ry Złote Mts. (Sudetes). Geol Q 40:89-118

Cymerman Z, Piasecki MAJ (1994) The terrane concept in the Sudetes, Bohemian Massif. Geol Q 38:191-210
Cymerman Z, Piasecki MAJ, Seston R (1997) erranes and terrane boundaries in the Sudetes, northeast Bohemian Massif. Geol Mag 134:717-725

De Paolo J (1981a) Neodymium isotopes in the Colorado Front Range and crust-mantle evolution in the Proterozoic. Nature 291:193-196

De Paolo J (1981b) A Nd and Sr isotopic study of Mesozoic calcalkaline batholiths of the Sierra Nevada and Peninsular Ranges, California. J Geophys Res 86:10370-10488

Depciuch T (1972) Absolute age of (K-Ar) granitoids from the Kłodzko-Złoty Stok area and the Niemcza Zone (in Polish, English summary). Kwart Geol 16:103-112

Domańska-Siuda J (2007) The granitoid Variscan Strzegom-Sobótka Massif. In: Kozłowski A, Wiszniewska J (eds) Granitoids in Poland. AM Monograph 1:179-191

Domečka K, Opletal M (1974) Granitoidy západni části orlicko-kladské klenby. Acta Univ Carol Geol 1:75-109

Dörr W, Zulauf G (2010) Elevator tectonics and orogenic collapse of a Tibetan-style plateau in the European Variscides: the role of the Bohemian shear zone. Int J Earth Sci (Geol Rundsch) 99:299-325

Dörr W, Żelaźniewicz A, Bylina P, Schastok J, Franke W, Haack U, Kulicki C (2006) Tournaisian age of granitoids from the Odra Fault Zone (southwestern Poland): equivalent of the MidGerman Crystalline High? Int J Earth Sci (Geol Rundsch) 95:341-349

Dudek A (1980) The crystalline basement block of the Outer Carpathians in Moravia: Bruno-Vistulicum. Rozpr České Akademie Věd, Řada matematických a přirodnich Véd 90:1-85

Dumicz M (1988) Złoty Stok-Skrzynka structural element in the light of mesostructural analysis of Ladek-Śnieżnik metamorphic terrain (in Polish, English summary). Geol Sudet 23(2):83-106

Dziedzicowa H (1963) So-called syenites of the Niemcza Zone (Lower Silesia) (in Polish, English summary). Arch Miner 24(2):5-126

Dziedzicowa H (1987) Structural evolution and metamorphism of eastern border of the Góry Sowie gneisses (in Polish, English summary). Acta Univ Wratisl 788 Prace Geol Miner 10:221-249

Finckh L (1925) Erläuterungen zur Geologische Karte von Preußen und benachbarten deutschen Ländern. Blatt Lauterbach, Berlin

Finger F, Hanžl P, Pin C, Von Quadt A, Steyrer HP (2000) The Brunovistulian: Avalonian Precambrian sequence at the eastern end of the Central European Variscides? In: Franke W, Haak V, Oncken O, Tanner D (eds) Orogenic processes: quantification and modelling in the Variscan Belt. Geol Soc London Spec Publ 179:103-112

Franke W (2000) The mid-European segment of the Variscides: tectonostratigraphic units, terrane boundaries and plate tectonic evolution. In: Franke W, Haak V, Oncken O, Tanner D (eds) Orogenic processes: quantification and modelling in the Variscan Belt. Geol Soc London Spec Publ 179:35-61

Franke W (2012) Comment on Dörr and Zulauf: elevator tectonics and orogenic collapse of a Tibetan-style plateau in the European Variscides: the role of the Bohemian shear zone. Int J Earth Sci (Geol Rundsch) 101:2027-2034

Franke W, Żelaźniewicz A (2000) The eastern termination of the Variscides: terrane correlation and kinematic evolution. In: Franke W, Haak V, Oncken O, Tanner D (eds) Orogenic processes: quantification and modelling in the Variscan Belt. Geol Soc London Spec Publ 179:63-86

Friedl G, Finger F, McNaughton NJ, Flechter IR (2000) Deducing the ancestry of terranes: SHRIMP evidence for South America-derived Gondwana fragments in central Europe. Geology 28:1035-1038 
Frost BR, Barnes CG, Collins WJ, Arculus RJ, Ellis DJ, Frost CD (2001) A geochemical classification for granitic rocks. J Petrol 11:2033-2048

Harvey PK, Atkin BL (1981) The rapid determination of Rb, Sr and their ratios in geological material by X-Ray fluorescence spectrometry using a Rhodium X-ray tube. Chem Geol 32:291-301

Haskin LA, Haskin MA, Frey FA, Wildman TR (1968) Relative and absolute terrestrial abundances of the rare earths. In: Ahrens LH (ed) Origin and distribution of the elements 1. Pergamon, Oxford, pp 889-911

Haydukiewicz J (2002) Thermal alteration of conodonts in Devonian to Lower Carboniferous rocks of the Góry Bardzkie Mts. (in Polish, English summary). Acta Univer Wratisl 2370. Prace Geol Miner 72:7-30

Hofmann AW (1988) Chemical differentiation of the earth: the relationship between mantle, continental crust, and oceanic crust. Earth Planet Sci Lett 90:297-314

Ilnicki S (2013) Metabasites of the Nové Město belt. AM Monograph No. 5 , pp 203

Kłapciński J, Juroszek C, Sachanbiński M (1975) New data on geology of the Fore-Sudetic crystalline basement (in Polish, English summary). Geol Sudet 10:7-49

Klomínský J, Jarchovský T, Rajpoot GS (2010) Atlas of plutonic rocks and orthogneisses in the Bohemian Massif. Introduction. Czech Geological Survey, Prague, p 95

Kozłowska-Koch M (1973) Polymetamorphites of the Złoty StokSkrzynka dislocation zone (in Polish, English summary). Geol Sudet 8:121-160

Kryza R, Crowley QG, Larionov A, Pin C, Oberc-Dziedzic T, Mochnacka K (2012) Chemical abrasion applied to SHRIMP zircon geochronology: an example from the Variscan Karkonosze Granite (Sudetes, SW Poland). Gondwana Res 21:757-767

Kryza R, Pin C, Oberc-Dziedzic T, Crowley QG, Larionov A (2014) Deciphering the geochronology of a large granitoid pluton (Karkonosze Granite, SW Poland): an assessment of U-Pb zircon SIMS and $\mathrm{Rb}-\mathrm{Sr}$ whole-rock dates relative to $\mathrm{U}-\mathrm{Pb}$ zircon CA-ID-TIMS. Int Geol Rev 56(6):756-782

Larionov AN, Andreichev VA, Gee DG (2004) The Vendian alkaline igneous suite of northern Timan: ion microprobe $\mathrm{U}-\mathrm{Pb}$ zircon ages of gabbros and syenite. In: Gee DE, Pease VL (eds) The Neoproterozoic Timanide Orogen of Eastern Baltic. Geol Soc London Mem 30:69-74

Laurent A, Janoušek V, Magna T, Schulmann K, Miková J (2014) Petrogenesis and geochronology of a post-orogenic calc-alkaline magmatic association: the Žulová Pluton, Bohemian Massif. J Geosci 59:415-440

Liew TC, Hofmann AW (1988) Precambrian crustal components, plutonic associations, plate environment of the Hercynian Fold Belt of central Europe: indications from a Nd and $\mathrm{Sr}$ isotopic study. Contrib Miner Petrol 98:129-138

Lorenc MW (1994) Role of basic magmas in the granitoid evolution (a comparative study of some Hercynian massifs (in Polish, English summary). Geol Sudet 28:3-130

Lorenc MW (1998) Rb-Sr isotopic study of the intrusive rocks from the Niemcza Zone (Lower Silesia, Poland) (in Polish, English summary). Arch Miner 51:153-164

Lorenc MW, Kennan PS (2007) Intrusive rocks from the Niemcza zone (Lower Silesia, Poland) in the light of petrologic and $\mathrm{Rb}-\mathrm{Sr}$ isotope studies. In: Kozłowski A, Wiszniewska J (eds) Granitoids in Poland. AM Monograph No. 1:253-259

Ludwig KR (2005a) SQUID 1.12 A user's manual. A Geochronological Toolkit for Microsoft Excel. Berkeley Geochronology Center Special Publication, 1-22. http://www.bgc.org/klprogrammenu.html
Ludwig KR (2005b) User's Manual for ISOPLOT/Ex 3.22. A Geochronological Toolkit for Microsoft Excel. Berkeley Geochronology Center Special Publication, 1-71. http://www.bgc.org/ klprogrammenu.html

Matte P, Maluski H, Rajlich P, Franke W (1990) Terrane boundaries in the Bohemian Massif: results of large-scale Variscan shearing. Tectonophysics 177:151-170

Mazur S, Józefiak D (1999) Structural record of Variscan thrusting and subsequent extensional collapse in the mica schists from vicinities of Kamieniec Ząbkowicki, Sudetic foreland, SW Poland. Ann Soc Geol Pol 69:1-26

Mazur S, Puziewicz J (1995) Mylonites of the Niemcza Fault Zone (in Polish, Fnglish summary). Ann Soc Geol Pol 64:23-52

Mazur S, Aleksandrowski P, Szczepański J (2005) The presumed Teplá-Barrandian/Moldanubian terrane boundary in the Orlica Mountains (Sudetes, Bohemian Massif): structural and petrological characteristics. Lithos 82:85-112

Mazur S, Aleksandrowski P, Kryza R, Oberc-Dziedzic T (2006) The Variscan Orogen in Poland. Geol Q 50:89-118

Mazur S, Aleksandrowski P, Turniak K, Awdankiewicz M (2007) Geology, tectonic evolution and Late Palaeozoic magmatism of Sudetes-an overview. In: Kozłowski A, Wiszniewska J (eds) Granitoids in Poland. AM Monograph 1:59-87

Mazur S, Szczepański J, Turniak K, McNaughton NJ (2012) Location of the Rheic suture in the eastern Bohemian Massif: evidence from detrital zircon data. Terra Nova 24:199-206. doi:10.1111/j.1365-3121.2011.01053.x

McLennan SM, Taylor SR, Hemming SR (2006) Composition, differentiation, and evolution of continental crust: constraints from sedimentary rocks and heat flow. In: Brown M, Rushmer $\mathrm{T}$ (eds) Evolution and differentiation of the continental crust. Cambridge University Press, Cambridge, pp 92-134

Meister E (1932) Erläuterungen zur Geologische Karte von Preußen und benachbarten deutschen Ländern. Blatt Gnadenfrei, Berlin

Mierzejewski MP, Pin C, Duthou JL, Couturie JP (1994) Sr-Nd isotopic study of the Karkonosze granite (Western Sudetes). In: Kryza R (ed) Igneous activity and metamorphic evolution of the Sudetes area. Abstracts. Second conference presenting results of French-Polish cooperation in geology between l'Université Blaise Pascal de Clermont-Ferrand and Wrocław University 1983-1993, p 82. University of Wrocław

Mikulski SZ, Williams JS (2014) Zircon U-Pb ages of granitoid apophyses in the western part of the Kłodzko-Złoty Stok Granite Pluton (SW Poland). Geol Q 58:251-262

Mikulski SZ, Williams JS, Bagiński B (2013) Early Carboniferous (Viséan) emplacement of the collisional Kłodzko-Złoty Stok granitoids (Sudetes, SW Poland): constrains from geochemical data and zircon U-Pb ages. Int J Earth Sci 102:1007-1027

Murtezi M (2006) The acid metavolcanic rocks of the Orlica-Śnieżnik Dome (Sudetes): their origin and tectono-metamorphic evolution. Geol Sudet 38:1-38

Nakamura N (1974) Determination of REE, Ba, Fe, Mg, Na and K in carbonaceous and ordinary chondrites. Geochim Cosmochim Acta 38:757-775

Nowak I (1998) Polyphase exhumation of eclogite-bearing highpressure mica schists from the Fore-Sudetic Block, SW Poland. Geol Sudet 31:3-31

Oberc J (1987) The Bardo Structure as a benchmark for the development of the Variscides in the Eastern part of the West Sudetes. (in Polish). Przewodnik 58 Zjazdu PTG. Wałbrzych 17-19 września 1987. ZG AGH, Kraków, pp 165-180

Oberc J (1995) Origin and liquidation of the terrane future strike-slip fault at the boundary between the Bardo Structure and the Złote Góry Metamorphic Complex (Sudeten, SW Poland) that precede granite (in Polish). Prz Geol 43:15-20 
Oberc J, Oberc-Dziedzic T (1978) Pre-Carboniferrous rocks of the western part of the Fore-Sudetic area (in Polish). Przewodnik 50 Zjazdu PTG. Zielona Góra 24-27 września 1978. Wydawnictwo Geologiczne, Warszawa, pp 97-108

Oberc-Dziedzic T, Kryza R (2012) Late stage Variscan magmatism in the Strzelin Massif (SW Poland): SHRIMP zircon ages of tonalite and Bt-Ms granite of the Gęsiniec intrusion. Geol Q 56:225-236

Oberc-Dziedzic T, Pin C, Duthou JL, Couturie JP (1996) Age and origin of the Strzelin granitoids (Fore-Sudetic Block, Poland): ${ }^{87} \mathrm{Rb} / 86 \mathrm{Sr}$ data. Neues Jb Miner Abh 171:187-198

Oberc-Dziedzic T, Żelaźniewicz A, Cwojdziński S (1999) Granitoids of the Odra Fault Zone: late- to post-orogenic Variscan intrusions in the Saxothuringian Zone, SW Poland. Geol Sudet 32:55-71

Oberc-Dziedzic T, Kryza R, Klimas K, Fanning MC (2003) SHRIMP $\mathrm{U} / \mathrm{Pb}$ zircon geochronology of the Strzelin gneiss, SW Poland: evidence for a Neoproterozoic thermal event in the Fore-Sudetic Block, Central European Variscides. Int J Earth Sci (Geol Rundsch) 92:701-711

Oberc-Dziedzic T, Kryza R, Pin C (2009a) The crust beneath the Polish Sudetes: evidence from a gneiss xenolith in Tertiary basanite from Paszowice. Geodin Acta 22:165-187

Oberc-Dziedzic T, Kryza R, Pin C, Mochnacka K, Larionov A (2009b) The Orthogneiss and Schist Complex of the Karkonosze-Izera Massif (Sudetes, SW Poland): U-Pb SHRIMP zircon ages, Nd-isotope systematics and protoliths. Geol Sudet 41:3-24

Oberc-Dziedzic T, Kryza R, Białek J (2010a) Variscan multistage granitoid magmatism in Brunovistulicum: petrological and SHRIMP U/Pb zircon geochronological evidence from the southern part of the Strzelin Massif, SW Poland. Geol Q $54: 301-324$

Oberc-Dziedzic T, Kryza R, Mochnacka K, Larionov A (2010b) Ordovician passive continental margin magmatism in the Central-European Variscides: U-Pb zircon data from the SE part of the Karkonosze-Izera Massif, Sudetes, SW Poland. Int J Earth Sci 99:27-46

Oberc-Dziedzic T, Kryza R, Pin C, Madej S (2013) Variscan granitoid plutonism in the Strzelin Massif (SW Poland): petrology and age of the Strzelin granites. Geol Q 57:269-288

Oliver GJH, Corfu F, Krough TE (1993) U-Pb ages from SW Poland: evidence for a Caledonian suture zone between Baltica and Gondwana. J Geol Soc Lond 150:355-369

Parry M, Štipská P, Schulmann K, Hrouda F, Ježek J, Krőner A (1997) Tonalite sill emplacement at an oblique plate boundary: northeastern margin of the Bohemian Massif. Tectonophysics 280:61-81

Passchier CV, Trouw AJ (2005) Microtectonics. Springer, Berlin, p 366

Paterson SR (2006) Close spatial relationship between plutons and shear zones: comment. Geology 33:e72

Paterson SR, Schmidt K (1999) Is there a close spatial relationship between faults and plutons? J Struct Geol 21:1131-1142

Peccerillo ASR, Taylor SK (1976) Geochemistry of Eocene calc-alkaline volcanic rocks from the Kastamoru area, northern Turkey. Contrib Miner Petrol 58:63-81

Pharaoh TC (1999) Palaeozoic terranes and their lithospheric boundaries within the Trans-European Suture Zone (TESZ): a review. Tectonophysics 314:17-41

Pietranik A, Waight T (2008) Processes and sources during Late Variscan dioritic-tonalitic magmatism: insights from plagioclase chemistry (Gęsiniec Intrusion, NE Bohemian Massif, Poland). J Petrol 49:1619-1645

Pietranik A, Storey C, Kierczak J (2013) The Niemcza diorites and monzodiorites (Sudetes, SW Poland): a record of changing geotectonic setting at c. $340 \mathrm{Ma}$. Geol Q 57:325-334
Pin C, Santos Zalduegui JF (1997) Sequential separation of light rare earth elements, thorium and uranium by miniaturized extraction chromatography: application to isotopic analyses of silicate rocks. Anal Chim Acta 339:79-89

Pin C, Binon M, Belin JM, Barbarin B, Clemens JD (1990) Origin of microgranular enclaves in granitoids: equivocal Sr-Nd evidence from hercynian rocks in the Massif Central (France). J Geophys Res Solid Earth (1978-2012) 95, B11:17821-17828

Przewłocki K, Magda W, Thomas HH, Faul H (1962) Age of granitic rocks in Poland. Geochim Cosmochim Acta 26:1069-1075

Puziewicz J (1988) Plagioclase pyroxene-biotite rock from the Koźmice quarry, Niemcza Zone (Sudetes, SW Poland): the first occurrence of vaugnerite in Polish Sudetes. Mineral Pol 19(2):59-65

Puziewicz J (1992) Origin of the Koźmice granodiorite (Niemcza Zone, Lower Silesia, Poland) (in Polish, English summary). Arch Miner 47(2):95-146

Richards JP (2001) Discussion of "Is there a close spatial relationship between faults and plutons?" by S.R. Paterson and K.L. Schmidt. J Struct Geol 23:2025-2027

Sachanbiński M (1980) The Fore-Sudetic granitoids in terms of geochemical data (in Polish, Fnglish summary). Arch Miner 36(1):135-242

Scheumann KH (1937) Zur Frage nach dem Vorkommen von Kulm in der Nimptscher Kristallinzone. Zeitschr für Krist Miner Petr Abt B Miner Petr Mitt 49:216-240

Schmidt KL, Paterson SR (2000) Analyses fail to find coupling between deformation and magmatism. Eos 81(197):202-203

Schulmann K, Gayer R (2000) A model for a continental accretionary wedge developed by oblique collision: the NE Bohemian Massif. J Geol Soc Lond 157:401-416

Stacey JS, Kramers JD (1975) Approximation of terrestrial lead isotope evolution by a two-stage model. Earth Planet Sci Lett 26:207-221

Steiger RH, Jäger E (1977) Subcommission on geochronology: convention on the use of decay constants in geo- and cosmochronology. Earth Planet Sci Lett 36:359-362

Suess E (1888) Das Antlitz der Erde, II. Tempsky, Wien

Sylvester AG, Ortel G, Nelson CA, Christie JM (1978) Papoose Flat pluton: a granitic blister in the Inyo Mountains, California. GSA Bull 89:1205-1219

Tait J, Bachtadse V, Franke W, Soffel HC (1997) Geodynamic evolution of the European Variscan fold belt: palaeomagnetic and geological constraints. Geol Rundsch 86:585-598

Thompson RN (1982) British Tertiary volcanic province. Scot J Geol 18:49-107

Turnau E, Żelaźniewicz A, Franke W (2002) Middle to early late Visean onset of late orogenic sedimentation in the Intra-Sudetic Basin, West Sudetes: miospore evidence and tectonic. Geol Sudet 34:9-16

Turniak K, Mazur S, Wysoczanski R (2000) SHRIMP zircon geochronology and geochemistry of the Orlica-Śnieżnik gneisses (Variscan belt of Central Europe) and their tectonic implications. Geodin Acta 13:1-20

Turniak K, Tichomirowa M, Bombach K (2005) Zircon Pb evaporation ages of granitoids from the Strzegom-Sobótka Massif (SW Poland). Miner Soc Pol Spec Pap 25:241-245

Turniak K, Tichomirowa M, Bombach K (2006) Pb-evaporation zircon ages from the Strzelin Massif (SW Poland). Miner Soc Pol Spec Pap 29:212-215

Turniak K, Mazur S, Domańska-Siuda J, Szuszkiewicz A (2014) SHRIMP U-Pb zircon dating for granitoids from the StrzegomSobótka Massif, SW Poland: constrains on the initial time of Permo-Mesosoic lithosphere thinning beneath Central Europe. Lithos 208-209:415-429 
Weinberg RF, Sial A, Mariano G (2004) Close spatial relationship between plutons and shear zones. Geology 32:377-380

Weinberg RF, Sial AN, Mariano G (2006) Close spatial relationship between plutons and shear zones: reply. Geology 33:e74

Werner T (2002) The correlation of magnetic anisotropies (AMS and AARM) with tectonic fabrics of the Niemcza Shear Zone (SW Poland). Acta Geophys Pol 50:80-107

Wiedenbeck M, Allé P, Corfu F, Griffin WL, Meier M, Oberli F, Von Quadt A, Roddick JC, Spiegel W (1995) Three natural zircon standards for U-Th- $\mathrm{Pb}$, Lu-Hf, trace element and REE analyses. Geostand Newsl 19:1-23

Wierzchołowski B (1976) Granitoids of the Kłodzko-Złoty Stok massif and their contact influence on the country rocks; petrographic characteristics (in Polish, Fnglish summary). Geol Sudet 11:7-147

Wierzchołowski B (1977) Dike rocks of the Kłodzko-Złoty Stok granitoid massif (in Polish, Fnglish summary). Geol Sudet 12(2):7-28

Wierzchołowski B (2003) Potassium-rich dyke rock of Rogówek (Sudetes, Poland). Arch Miner 54:77-97

Williams IS (1998) U-Th-Pb Geochronology by ion microprobe. In: Applications in microanalytical techniques to understanding mineralizing processes. Rev Econ Geol 7:1-35

Wojciechowska I (1975) Tectonics of the Kłodzko-Złoty Stok granitoide massif and its country rocks in the light of the mesostructural investigation (in Polish, English summary). Geol Sudet 10(2):61-121
Zeh A, Brätz H, Millar IL, Williams IS (2001) A combined zircon SHRIMP and Sm-Nd isotope study of high-grade paragneisses from the Mid-German Crystalline Rise: evidence for northern Gondwana and Grenvillian provenance. J Geol Soc Lond 158:983-994

Żelaźniewicz A (1977) Granitoids of the Kudowa-Olešnice massif (Sudetes). Geol Sudet 12(1):137-162

Żelaźniewicz A (2005) Przeszłość geologiczna. In: Dolnego Przyroda (ed) Fabiszewski J. Ślaska, PAN Wrocław, pp 61-134

Żelaźniewicz A, Marheine D, Oberc-Dziedzic T (2003) A Late Tournaisian synmetamorphic folding and thrusting event in the eastern Variscan foreland: 40Ar/39Ar evidence from the phyllites of the Wolsztyn-Leszno High, western Poland. Int J Earth Sci (Geol Rudsch) 92:185-194

Żelaźniewicz A, Buła Z, Fanning M, Seghedi A, Żaba J (2009a) More evidence on Neoproterozoic terranes in Southern Poland and southwestern Romania. Geol Q 53:93-124

Żelaźniewicz A, Fanning CM, Achramowicz S (2009b) Refining the granite, gneiss and schist interrelationships within the LusatianIzera Massif, West Sudetes, using SHRIMP U-Pb zircon analyses and new geologic data. Geol Sudet 41:67-84

Żelaźniewicz A, Jastrzębski M, Redlińska-Marczyńska A, Szczepański J (2014) The Orlica-Śnieśnik Dome, the Sudetes, in 2002 and 12 years later. Geol Sudet 42:105-123 